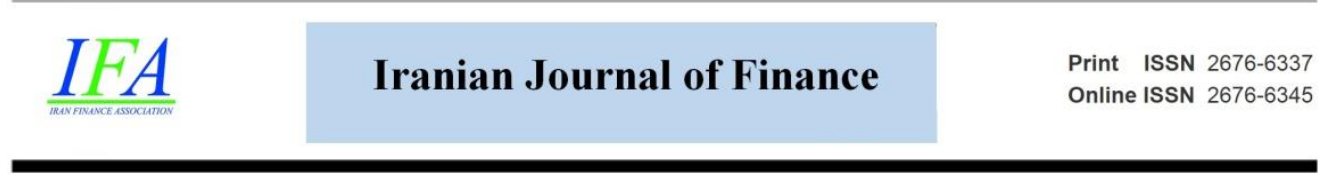

\title{
Auditors' Wise Tactfulness in Professional Judgments by Total Interpretive Structural Modeling (TISM)
}

\section{Hadi Malekipour}

Ph.D. Candidate, Department of Accounting, Shahroud Branch, Islamic Azad University, Shahroud, Iran. (Email: hadi282m@yahoo.com)

\section{Mohammadreza Abdoli*}

*Corresponding Author, Associate Prof., Department of Accounting, Shahroud Branch, Islamic Azad University, Shahroud, Iran. (Email: mra830@yahoo.com)

\section{Hasan Valiyan}

Assistant Prof., Department of Accounting, Shahroud Branch, Islamic Azad University, Shahroud, Iran. (Email: hasan.valiyan@yahoo.com)

Document Type: Original Article

Received: 2020/11/09
2021, Vol. 5, No. 2. 95-127.

Published: 2021/04/26

\section{Abstract}

Since the auditing profession is a process engaged in judgment activities, knowing the reasoning concepts to achieve a level of rationale in audit judgment is the theoretical and fundamental concept in this profession. In this regard, tactfulness is one of the decision-making components in an auditor's judgment that assigns a level of reasoning for making an intellectual decision and promotes the level of judgment quality in auditing. Accordingly, the purpose of this research is Auditors' Wise Tactfulness in Professional Judgments by Total Interpretive Structural Modeling (TISM). The mixedmethods approach was used for the research in which, in the qualitative part, two experts population as panel members, and, in the quantitative part, 30 independent auditors as the statistical population participated. In the qualitative part, the meta-analysis approach was used to identify the themes related to wise tactfulness in professional judgment, and then, the basic themes selected were examined based on two criteria, concordance coefficient and average, in three rounds reciprocally until theoretical saturation was met. At this point, 14 themes were accepted among 20 basic themes. In the quantitative part, the themes accepted were coded first and then were distributed among the respective population, based on a matrix questionnaire, to identify the most 
effective trait of auditor's wise tactfulness in professional judgment using the Total Interpretive Structural Modeling approach. According to the results, the theme adherence to the principles of professional ethics as a basic theme of professional thinking was selected as the most influential trait of wise tactfulness.

Keywords: Wise tactfulness, Professional judgment, Total Interpretive Structural Modeling

DOI: 10.30699/IJF.2021.256524.1171

Publisher: Iran Finance Association

Copyright: author(s)

Type of License: Creative Commons License (CC-BY 4.0)

\section{Introduction}

Looking for wisdom has a history, almost as old as human life, built by the efforts of philosophers and thinkers in various science areas such as philosophy, social sciences, management, and psychology, and recently, it has entered into the auditing profession because of its importance in decisionmaking (Paranoan et al., 2018). Although this area is developing, wisdom is a far-reached human quality that hardly is conceptualized and operative because it is very difficult and lasting to recognize the dimensions of wisdom in an individual's decision due to its internal complexity (Sternberg, 2004). On the other hand, tactfulness in decision-making is a kind of insight and philosophical and social cognition about the issue under consideration that may bring responsibility for the individual. The integration of tactfulness and wisdom is a kind of individual's (auditor's) internal perception in decisionmaking, facilitating the individual to achieve cognition in making a decision accepted by intuitive feeling to be the best option (Windhorst, 2011). Decisionmaking in auditing is a kind of reasoning before a judgment causing the auditor's judgment to be shaped based on the auditor's internal and external approaches. Indeed, judgment and decision-making are the basic elements of auditing that paying attention to their unknown content dimensions can help to develop the science in this area (MashayekhiFard et al., 2019). In other words, decision-making and consequently professional judgment, which is the vital and important part of all auditing processes, as well as identifying the traits such as wise tactfulness, which is based on auditor's philosophical insight, can help to improve the quality of financial statements review by auditors. Consequently, the level of transparency in beneficiaries' decisions is increased. Wise tactfulness is a kind of maturity in decision-making based on thought and 
internal characteristics of auditing, which in the idiomatic sense is called more elaborate decision-making (Valiyan et al., 2019). In this regard, Small (2004) argued that in today's atmosphere that lacks transparency, the need for wise tactfulness in decision-making is felt to understand the nature of wisdom and knowledge completely to review financial statements by auditors. Indeed, wisdom is a multifaceted concept originating from cognition, act, and human emotions and combines subjectivity with objectivity (Valentine and Godkin, 2019). Wise tactfulness exhibits itself through turning interests, values, beliefs, and judgments into content to realize the goals. From another perspective, wisdom exploits the individual's strengths in the scope of judgment and selection through subjective frameworks and enriches decision-making (Rooney et al., 2013). In recent years, researchers tend to conduct empirical researches on the role of wise tactfulness in decision-making in the areas of human sciences such as decision-makers internal and external approaches, and they argue that wise tactfulness helps auditors correctly judge when making decisions. Despite the recent emphasis on the vital role of wisdom in decisionmaking, existing studies in the area of wisdom and intuition in auditing scope do not provide analysts and theorists of auditing with sufficient and appropriate information concerning making proper decisions in this profession due to neglecting the importance of wisdom in decision-making. Nevertheless, the theoretical perception of the concept of wise tactfulness in auditor's decisionmaking can be considered as a pivot in judgmental contexts of auditors (Csikszentmihalyi and Rathunde, 1990). While there is increasing attention to the theory of wisdom in various fields, integrating wisdom into professional methods such as auditing, especially in their decision-making and professional assertions about financial statements, is yet vague. This gap is expanded regarding the lack of an empirical and explicit understanding of the relationship between wisdom and auditors' decision-making (Mollanazari and Esmaeilikia, 2014). Therefore, this research aims to conceptualize wise tactfulness in auditor's professional behaviors along with auditing standards to make the best decision for audit judgment. First, it is tried to identify the research components and indicators based on the meta-synthesis method through a content analysis of relevant researches and studies. Then, the most important dimensions of an auditor's wise tactfulness in professional judgment are prioritized using Total Interpretive Structural Modeling. Regarding the discussions above, this research aims to identify and prioritize the factors of auditor's wise tactfulness in professional judgment. Accordingly, in Section 2, along with theoretical foundations, the motivation for conducting the research is explained, and conceptual expansion of the research with applied and researched arguments are stated. In Section 3, the methodology, participants, 
and data collection and research validation tools are described to provide a more coherent path of research contents. In Section 4, the research model is presented using Total Interpretive Structural Modeling through matrix questionnaires. Finally, discussions on the results, along with recommendations, are provided in Section 5.

\section{Research Background}

\section{Wisdom in contents of the auditing profession}

From the classic perspective, wisdom is a feature that examines the correctness of judgments in critical conditions (Melé, 2010) related to itself or other ones. Wisdom, which is associated with correct judgment and the use of knowledge in life, is conceptualized in two ways:

- Sophia (Pure or theoretical wisdom)

- Phronesis (Prudence or practical wisdom)

While theoretical wisdom addresses internal truth, practical wisdom deals with behaviors and considers the right behavior in a specified condition and time. In other words, theoretical wisdom investigates that what is the true work to do, while practical wisdom entails an ability to do the work. The origin of the concept of wisdom has attracted the attention of many researchers in various fields in recent academic studies. First, in the field of philosophy, and then in Psychology, leadership, organizational studies, management, auditing, and other scopes, researchers pursue the conceptualization and content of the word wisdom. In the area of auditing, the concept of wisdom and wise decision-making based on individual capabilities have been discussed in recent years, and this issue mostly has been originated from the perspective of auditors' judgments in financial statements review (Baltes and Smith, 1990). Note that wisdom in auditors' decision-making is defined as the integration of cognitive and reflective features, and it is not considered a public characteristic and is not necessarily based on an individual's skill and technical and expert knowledge. In other words, Bergsma and Ardelt (2012) stated that wisdom is specific to wise and aware individuals, and it should not be considered as an individual feature. On the other hand, auditing research on the role of wisdom in auditors' decision-making concerning financial statements have shown a tendency to critic the Berlin school that says wisdom is not always stable, and a person may, sometimes, make a decision out of wisdom. Therefore, it is implied that individuals may not behave wisely in all situations (Richardson and Pasupathy, 2005; Sternberg, 2004). Sternberg's balance theory shows that wisdom in auditors' decision-making is the use of intelligence and experience 
based on values to realize a win-win relationship through building a balance among auditor's intrapersonal, interpersonal, and extrapersonal interests in the short and long term to create a balance among adaptation of the existing environment, shaping the existing environment, or choosing a new environment. In other words, balance theory regards wisdom as individuals' consistency with different situations.

\section{Wise tactfulness in judgment}

Rational thinking, which is the basis of individuals' advancement, is a background for the presence of wise tactfulness to achieve maturity in decision-making. In other words, an individual chooses a kind of thinking for his/her professional challenges through wise tactfulness based on step-by-step and intellectual processes (Dunn, 2005). Indeed, wise tactfulness is an effective factor in an auditor's subjective inferences to make a more useful and relevant to realities. Radcliffe (1998) introduced wise tactfulness as a subjective philosophy and defined it based on a step-by-step process to achieve a desired level of decision-making and thought. On the other hand, Lenz (2008), in line with wise tactfulness, discussed rationality in decision-making and audit judgment and defined auditors' tactful attitude with features such as comprehensiveness, scrutiny, and flexible attitude toward the auditing profession. Accordingly, an auditor, who benefits from rational tactfulness, always tries to adopt a comprehensive and generalizable thought based on which he/she analyzes the issues and challenges of the auditing profession concerning multidimensional contexts to reach a comprehensive interest. Besides, he/she selects a more path beyond his/her subjective assumptions and clichés without prejudice by questioning the trivial issues in the auditing profession (Lam and Mensah, 2016). On the other hand, the auditor's wise tactfulness causes the individual to investigate the cases of a decision based on thought approaches such as theosophy and intuition through contemplation in auditing challenges and flexible attitude to use more behavioral and professional coherence in their judgment. Indeed, wise tactfulness cause auditors to, besides paying attention to making a satisfactory decision through a gradual process, try to achieve the best decision for judgment based on rational decision-making principles step-by-step. This is because decision-making refers to a set of mental activities occurring when making a decision about creating or selecting among various solutions (Schraagen et al., 2008), and it can be wise (intellectual) or gradual (satisfactory), depending on the individual's approach (Ejabi et al., 2012). Therefore, presently, one of the intricacies of accounting and auditing needing attention is to consider the criteria of decision-making by auditors, which has not been addressed in any 
standard document. Decision-making is an activity included in all auditing processes, and the necessity of attention to features such as professionalism leads to an increase in the expected quality of auditors' judgments. From the perspective of behavioral theories of auditing, the auditor is a special individual with technical knowledge in a special environment, time, and place and different from all his/her previous reviews. In these situations, the auditor should focus on special and behavioral scopes with a macro perspective and try to maintain its communications with clients from the business viewpoints (Lynch et al., 2009). It is believed in professional decision-making or judgments that auditors can make realistic statements based on ethical behaviors to increase transparency using their technical knowledge experience (Zsambok, 1997). While traditional theories believed that, according to wise approaches and based on normative models, optimal decisions should be made based on step-by-step decision-making principles, behavioral and cognitive approaches believed in the impact of complex environments in decisionmaking processes and built the decision based on auditors' internal powers such as intuition. Indeed, decision-making changes its direction from a step-bystep process to judgmental processes that are based on auditors' perceptions, and focus more on practical aspects of decision-making. Decision-making always faces concepts such as pragmatism (Windhorst, 2011). Indeed, "pragmatic," "practical," "problem-solving," and "responding to an environment" are similar concepts that can be considered in the conceptualization of the expression "wise decision-making" in the auditing profession. Lam and Mensah (2016) stated that when one says an auditor takes a decision, three concepts occur in our mind:

1. He/she has started a set of actions in line with doing the work.

2. He/she has prepared its mind for doing a special task free from the previous frameworks.

3. He/she presented an opinion or viewpoint concerning the point that, in a special condition, an individual should take action after proposing alternative solutions.

Therefore, understanding the decisions of an auditor in reviewing financial statements based on a conceptualization of wisdom can help mental concepts to be more in line with the practical realities of the companies because decision-making has received little attention in the auditing context.

\section{Methodology}

In recent years, with an increase in the number of researches in various fields of sciences and the emergence of information explosion to the scientific 
community, there is a rapid growth in the use of mixed researches in which the essence of researches published on a special issue is extracted systematically and scientifically (Azkia and Tavakkoli, 2016). One of the approaches developed to investigate, combine, and conceptualize scientific content is the meta-analysis approach. This approach is one of the dimensions of the metastudy approach that analyzes the findings of relevant previous researches (Stirling, 2001). The present study, which is mixed research, uses the metaanalysis approach in the qualitative part. The meta-analysis includes steps to find the components and factors. Maybe, the most important steps in this approach are the seven steps of Sandelowski and Barroso (2008) that consist of several stages from recognizing the problem origin through formulating the research question to providing a clear model based on the identification of components and factors using the previous researches (Andrel et al., 2009). Then, in the quantitative part, the most influential factors are identified using Total Interpretive Structural Modeling and presented by a hierarchical model. Accordingly, the research approach used in this research is inductive-deductive regarding the data collection process. In short, first, the factors related to auditor's wise tactfulness in professional judgment are identified by investigating the theoretical foundations based on the meta-analysis approach, and then, the factors are accepted or rejected using the Delphi method based on two criteria, namely, average and concordance coefficient. Finally, in the quantitative part, the levels identified are prioritized in the form of a model and explained in terms of driving power and influence power in the auditing profession.

\section{Research questions}

The research is centered on the following questions:

In the qualitative part: What are the factors of an auditor's wise tactfulness in professional judgment?

In the quantitative part: What is the most influential factor of an auditor's wise tactfulness in professional judgment?

\section{Statistical population}

Regarding the type of research, participants are divided into two groups in qualitative and quantitative parts. In the qualitative part, the population consists of relevant researches and 16 experts in the accounting field that contribute to the analysis and identification of components and factors. In other words, these participants cooperated in two parts of meta-analysis and Delphi analysis. These participants, as the members of the panel group, were selected through homogeneous sampling in which the researcher, aiming at acquiring a deep, centralized and elaborated knowledge, chooses the members among those who 
experience the phenomenon and may provide the researcher with valuable information (Sadeghi Fasaei and Nasseri Rad, 2012). In the quantitative part, the population consisted of 30 independent auditors. Regarding the requirements of Total Interpretive Structural Modeling, the size of the statistical population is acceptable and, it is expected that the population help to explain the results of the qualitative part in the auditing profession. Since Total Interpretive Structural Modeling is an analysis based on a resolution of complex systems at a specified level that is required to be conducted based on a specified criterion such as experience or expert knowledge by participants, cross-matrix questionnaires were used with 15 to 30 participants to avoid from the accumulation of insensible responses. Singh and Kant (2011), Malone (2014), Ramesh et al. (2010), Attri et al. (2013) introduced the range 15 to 30 for the desired size of the sample and suggested Convenience Sampling regarding the filters relevant to the nature of the study.

\section{Research Findings}

\section{Results of the meta-analysis}

To conduct the meta-analysis, first, the total number of valid and reliable researches is determined according to the following process using the databases and scientific archives such as SID, MAGIRAN, NOORSOFR, Sciencedirect, Emeraldinsight, and OnlineLibrary. The relevant researches are identified using the above databases.

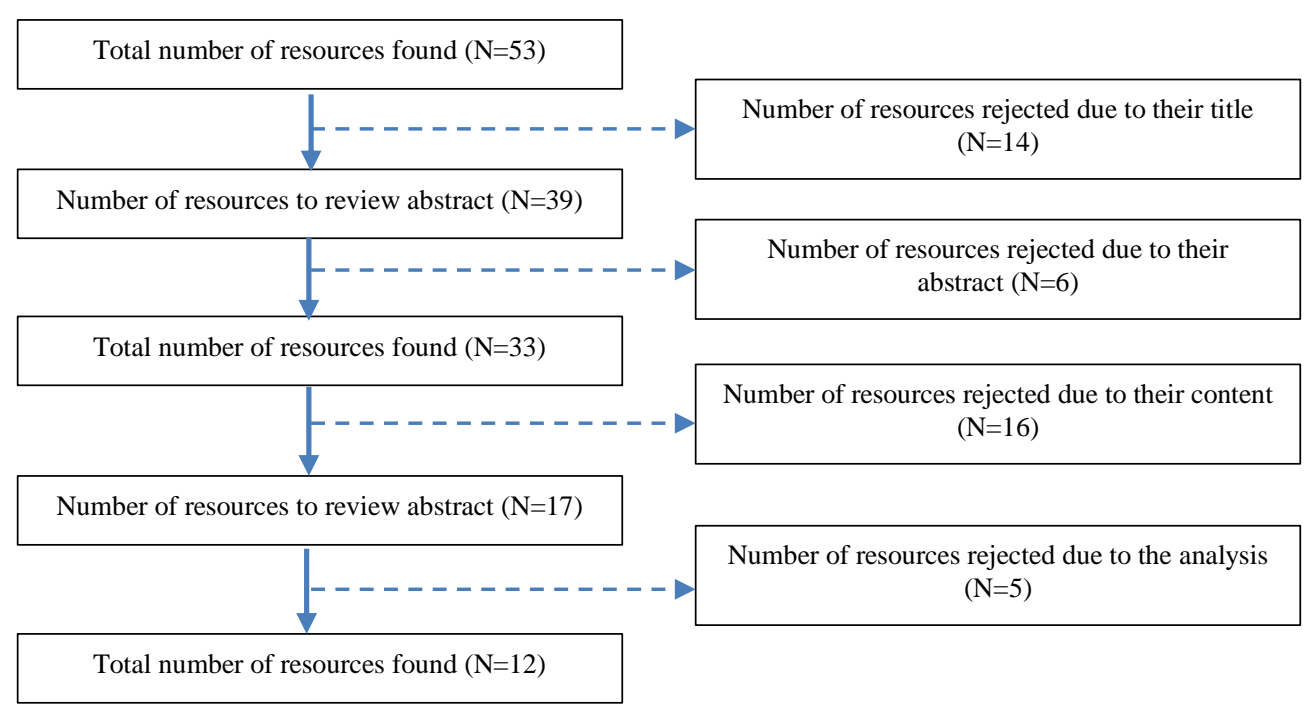

Figure 1. Determining the appropriate studies and articles to identify the components and factors 
As seen in Figure 1, 12 pieces of research were accepted concerning the content. In the next step, the themes are classified and discriminated as the components and factors related to the research subject according to the approach proposed by Stirling (2001). First, the researches accepted are fitted again by 16 members of the research panel to achieve a more coherent perception regarding the nature of the research through 10 criteria of the critical appraisal including research purposes, the rationale of research method, research design, sampling, data collection, reflectivity, precise analysis, theoretical and transparent statement of findings, and research value.

Table 1. Critical appraisal of researches identified

\begin{tabular}{|c|c|c|c|c|c|c|c|c|c|c|c|c|}
\hline $\begin{array}{l}\text { Critical appraisal } \\
\text { criteria/Research }\end{array}$ & 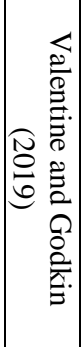 & 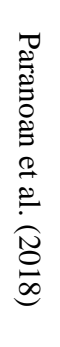 & 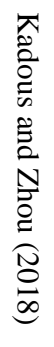 & 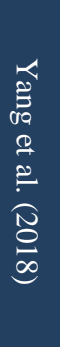 & 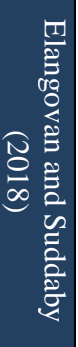 & 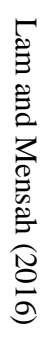 & 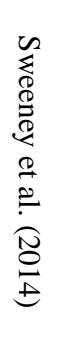 & 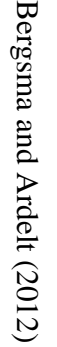 & $\begin{array}{l}\frac{3}{0} \\
\frac{0}{2} \\
\stackrel{0}{0} \\
0\end{array}$ & 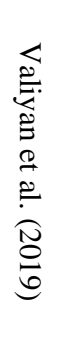 & 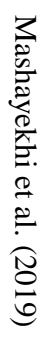 & 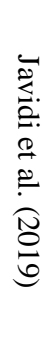 \\
\hline Research purpose & 4 & 3 & 3 & 2 & 3 & 4 & 3 & 3 & 3 & 4 & 5 & 3 \\
\hline $\begin{array}{l}\text { The rationale of the research } \\
\text { method }\end{array}$ & 3 & 4 & 3 & 3 & 2 & 3 & 3 & 3 & 3 & 3 & 3 & 4 \\
\hline Research design & 3 & 5 & 3 & 2 & 2 & 4 & 3 & 4 & 3 & 4 & 3 & 4 \\
\hline Sampling method & 4 & 4 & 4 & 3 & 3 & 4 & 4 & 3 & 3 & 3 & 3 & 4 \\
\hline Data collection method & 4 & 4 & 3 & 3 & 3 & 4 & 3 & 3 & 4 & 5 & 3 & 3 \\
\hline Generalization & 3 & 3 & 3 & 2 & 2 & 4 & 3 & 4 & 3 & 3 & 4 & 3 \\
\hline Ethical approaches & 4 & 4 & 4 & 3 & 2 & 4 & 4 & 3 & 3 & 4 & 3 & 4 \\
\hline Statistical analysis of results & 4 & 3 & 4 & 3 & 3 & 4 & 3 & 3 & 3 & 3 & 4 & 3 \\
\hline Research value & 3 & 4 & 4 & 1 & 1 & 3 & 4 & 5 & 5 & 5 & 5 & 4 \\
\hline Total & 32 & 34 & 31 & 22 & 20 & 34 & 30 & 31 & 30 & 34 & 33 & 32 \\
\hline
\end{tabular}

As observed in Table 1, the two research of Yang et al. (2018) and Elangovan and Suddaby (2018) gain a score less than 30 by the panel members, and consequently, these two pieces of research are removed. Now, the themes are extracted from the accepted researches based on the Stirling method (2001). First, the texts selected from the resources of studies should be coded as the basic themes to be able to combine these various and seemingly irrelevant themes properly. The total codes obtained from the researches accepted by the critical appraisal process amount to 88 themes that part of which are presented in Table 2 . 
104 Iranian Journal of Finance, 2021, Vol. 5, No. 2 (Malekipour, F.)

Table 2. Some basic themes of the research

\begin{tabular}{|c|c|}
\hline Content extracted & Basic theme \\
\hline $\begin{array}{l}\text { 1. Although in the auditing profession, decision-making has specific rules } \\
\text { and should be in line with corresponding standards, based on individual } \\
\text { differences, auditors' decision-making should be based on social motives } \\
\text { such as accountability and responsiveness (Kadous and Zhou, 2018). }\end{array}$ & $\begin{array}{l}\text { 1. Accountability } \\
\text { 2. Responsiveness }\end{array}$ \\
\hline $\begin{array}{l}\text { 6. Self-awareness causes auditors not only to have a realistic image of } \\
\text { themselves but also realize the relationships between managers and the } \\
\text { surrounding environment by appropriately integrating abilities and } \\
\text { strengths for decision-making (Valiyan et al., 2019). }\end{array}$ & 7. Self-awareness \\
\hline $\begin{array}{l}\text { 9. Audit judgment is efficient when the auditor be able to balance his/her } \\
\text { subjectivities with professional performances in the auditing path (Sweeney } \\
\text { et al., 2014). }\end{array}$ & $\begin{array}{l}\text { 11. correlation between } \\
\text { subjectivity and } \\
\text { professional performances }\end{array}$ \\
\hline $\begin{array}{l}\text { 17. Being active in several works simultaneously and beyond the specified } \\
\text { time is a fact contrary to professional thinking and attention to the interests } \\
\text { of the majority of the stakeholders (Javidi et al., 2019). }\end{array}$ & $\begin{array}{l}\text { 21. Considering the } \\
\text { interests of the majority of } \\
\text { the stakeholders }\end{array}$ \\
\hline $\begin{array}{l}\text { 24. Achieving cognition in the auditing profession is an important factor in } \\
\text { an auditor's judgment. Cognition is created gradually in the career path by } \\
\text { breaking the subjective reference frameworks and causes the individual to } \\
\text { be more committed to justice in this profession (Valiyian et al., 2019). }\end{array}$ & $\begin{array}{l}\text { 27. Breaking the } \\
\text { subjective reference } \\
\text { frameworks } \\
\text { 28. Committing to justice } \\
\text { in the auditing profession }\end{array}$ \\
\hline $\begin{array}{l}\text { 25. The decision-maker should benefit from a deep perception beyond the } \\
\text { target matter to be able to act with wise tactfulness and bring the most } \\
\text { interest to him/her and others (Melé et al., 2010). }\end{array}$ & $\begin{array}{l}29 . \text { Deep perception } \\
\text { beyond the target matter }\end{array}$ \\
\hline $\begin{array}{l}\text { 33. Professional auditors should have the capability to recognize their } \\
\text { perceptual features to reduce tensions in critical situations to be able to } \\
\text { eliminate judgment biases (Lam and Mensah, 2016). }\end{array}$ & $\begin{array}{l}\text { 36. Recognizing the } \\
\text { perceptual faults }\end{array}$ \\
\hline $\begin{array}{l}\text { 39. Intuition in decision-making is necessary to succeed in achieving the } \\
\text { goals (Valentine and Godkin, 2019) }\end{array}$ & $\begin{array}{l}\text { 43. Intuition in decision- } \\
\text { making }\end{array}$ \\
\hline $\begin{array}{l}\text { 51. An auditor having intuitive thinking, to make the best decision, should } \\
\text { acquire sufficient knowledge related to the changes in the capital market } \\
\text { and clients' characteristics based on his/her experiences (Lam and Mensah, } \\
\text { 2016). }\end{array}$ & $\begin{array}{l}\text { 53. intuitive thinking } \\
\text { 54. Knowing the capital } \\
\text { market } \\
\text { 55. Knowing the clients }\end{array}$ \\
\hline $\begin{array}{l}\text { 54. Libby and Luft (1993) considered the audit judgment performance as a } \\
\text { function of environmental, experience and recognition motivations that } \\
\text { increase the auditor's effectiveness level (Mashayekhi Fard et al., 2019) }\end{array}$ & $\begin{array}{l}\text { 59. Environmental } \\
\text { knowledge } \\
\text { 60. Auditor's experience }\end{array}$ \\
\hline $\begin{array}{l}\text { 57. Individuals' abilities, even if they are exclusive, have an important role } \\
\text { in learning and the promotion of audit judgment level to deal with critical } \\
\text { situations in the auditing profession (Mashayekhi Fard et al., 2019). }\end{array}$ & $\begin{array}{l}\text { 63. Individual abilities in } \\
\text { professional complexities }\end{array}$ \\
\hline $\begin{array}{l}\text { 59. Auditors having experience and technical knowledge consider } \\
\text { multidimensional viewpoints, appraise expansionary interpretations, find } \\
\text { common meanings, and attain a combined viewpoint that solves the } \\
\text { problem (Valiyan et al., 2019). }\end{array}$ & $\begin{array}{l}\text { 65. Experience in auditing } \\
\text { 66. Having inferential } \\
\text { interpretations }\end{array}$ \\
\hline $\begin{array}{l}\text { 66. A professional norm in auditing is to move inside the framework of } \\
\text { ethical rules and elements that, if observed properly, represent the } \\
\text { congruence between perceptions and professional features of auditing and } \\
\text { its maturity (Paranoan et al., 2018). }\end{array}$ & $\begin{array}{l}\text { 69. Moving in line with } \\
\text { regulations } \\
\text { 70. Obeying the ethical } \\
\text { elements } \\
\text { 71. Congruence between } \\
\text { perceptions and } \\
\text { professional features of } \\
\text { auditing }\end{array}$ \\
\hline 69. Auditor's tactfulness and accordance to wisd & 74. Maintaining emotions \\
\hline
\end{tabular}




\begin{tabular}{|c|c|}
\hline $\begin{array}{c}\text { not realized easily, and these are idealistic and theosophical senses that are } \\
\text { achieved gradually and relatively by maintaining emotions and emotional } \\
\text { balance, and it ends in insight and intuition in making the best decision } \\
\text { (Paranoan et al., 2018). }\end{array}$ & $\begin{array}{c}\text { 75. Emotional balance } \\
\text { 76. Insight and intuition in } \\
\text { decision-making }\end{array}$ \\
\hline $\begin{array}{c}\text { 77. Since one of the individual characteristics is the mental and intuitive } \\
\text { power, in each testing and reporting process such as auditing that includes } \\
\text { judgment, breaking the subjective presumptions is necessary to achieve the } \\
\text { best judgment (Mashayekhi Fard et al., 2019). }\end{array}$ & $\begin{array}{c}\text { 79. Mental and intuitive } \\
\text { power } \\
\text { 80. Breaking the } \\
\text { subjective presumptions }\end{array}$ \\
\hline $\begin{array}{c}\text { 79. Recognition in auditing is a vague issue and is based on a free } \\
\text { understanding specific to each individual. However, achieving recognition } \\
\text { in auditing requires an elaborated thought and is beyond the auditing } \\
\text { profession (Sweeney et al., 2014). }\end{array}$ & $\begin{array}{c}\text { 82. Recognition } \\
\text { 83. Looking beyond } \\
\text { 84. Deepening the thought }\end{array}$ \\
$\begin{array}{c}\text { 81. Recognizing the } \\
\text { 8ubjective contradictions } \\
\text { subjective contradiction of realities. This feature is seen in the form of } \\
\text { perceptual faults and biases in decision-making (Bergsma and Ardelt, } \\
\text { 2012). }\end{array}$ & $\begin{array}{c}\text { perceptual biases in } \\
\text { decision-making }\end{array}$ \\
\hline
\end{tabular}

Due to restriction on the pages of the journal, we present a part of the themes. It should be noted that among 118 contents extracted, 88 initial themes are determined that, among all, ultimately 20 basic themes are selected and summarized as three organizing themes (components) as presented in Table 3.

Table 3. The themes identified for factors of auditor's wise tactfulness in professional judgment

\begin{tabular}{|c|c|}
\hline $\begin{array}{l}\text { Organizing theme } \\
\text { (component) }\end{array}$ & Basic themes (factors) \\
\hline \multirow{8}{*}{ Professional thinking } & Learning in the career path \\
\hline & Considering the interests of the majority of the stakeholders \\
\hline & Evaluating individual abilities in professional complexities \\
\hline & Evaluating the values of the auditing profession \\
\hline & Developing individual knowledge in the career path \\
\hline & Creating a congruence between subjectivity and professional performance \\
\hline & Having inferential interpretations \\
\hline & Committing to professional ethics \\
\hline \multirow{5}{*}{ Social thinking } & Focusing on social and responsive approaches related to society \\
\hline & Moving in line with regulations and standards defined \\
\hline & $\begin{array}{l}\text { Respecting qualitative elements such as uncertainty and neutrality in the } \\
\text { auditing profession }\end{array}$ \\
\hline & Respecting fairness and justice \\
\hline & Responsiveness and sobriety \\
\hline \multirow{7}{*}{ Cognitive thinking } & $\begin{array}{l}\begin{array}{l}\text { Recognizing the special features of the capital market (such as culture and } \\
\text { the type of industry) }\end{array} \\
\end{array}$ \\
\hline & Deepening the thoughts beyond the scope of the auditing profession \\
\hline & Recognizing the judgment biases in the auditing profession \\
\hline & Looking ahead when making decisions \\
\hline & $\begin{array}{l}\text { Breaking the subjective reference frameworks to achieve professional } \\
\text { recognition }\end{array}$ \\
\hline & $\begin{array}{l}\text { Controlling the emotions when facing complexities of the auditing } \\
\text { profession }\end{array}$ \\
\hline & Balanced reliance on insight and intuition in professional decision-making \\
\hline
\end{tabular}


Now, the following checklist is designed and distributed among the population in the qualitative part to control the quality of the themes using the validity and reliability analysis and Delphi analysis of the themes selected.

Table 4. Seven-point checklist

\begin{tabular}{|c|c|c|c|c|c|c|c|c|}
\hline $\begin{array}{l}\text { Organizing theme } \\
\text { (component) }\end{array}$ & Basic themes (Factors) & 1 & 2 & 3 & 4 & 5 & 6 & 7 \\
\hline \multirow{8}{*}{ Professional thinking } & Learning in the career path & & & & & & & \\
\hline & $\begin{array}{l}\text { Considering the interests of the majority of the } \\
\text { stakeholders }\end{array}$ & & & & & & & \\
\hline & $\begin{array}{l}\text { Evaluating individual abilities in professional } \\
\text { complexities }\end{array}$ & & & & & & & \\
\hline & Evaluating the values of the auditing profession & & & & & & & \\
\hline & $\begin{array}{l}\text { Developing individual knowledge in the career } \\
\text { path }\end{array}$ & & & & & & & \\
\hline & $\begin{array}{l}\text { Creating a congruence between subjectivity and } \\
\text { professional performance }\end{array}$ & & & & & & & \\
\hline & Having inferential interpretations & & & & & & & \\
\hline & Committing to professional ethics & & & & & & & \\
\hline \multirow{5}{*}{ Social thinking } & $\begin{array}{l}\text { Focusing on social and responsive approaches } \\
\text { related to society }\end{array}$ & & & & & & & \\
\hline & $\begin{array}{l}\text { Moving in line with regulations and standards } \\
\text { defined }\end{array}$ & & & & & & & \\
\hline & $\begin{array}{l}\text { Respecting the qualitative elements such as } \\
\text { uncertainty and neutrality in the auditing } \\
\text { profession }\end{array}$ & & & & & & & \\
\hline & Respecting fairness and justice & & & & & & & \\
\hline & Responsiveness and sobriety & & & & & & & \\
\hline \multirow{7}{*}{ Cognitive thinking } & $\begin{array}{l}\text { Recognizing the special features of the capital } \\
\text { market (such as culture and the type of industry) }\end{array}$ & & & & & & & \\
\hline & $\begin{array}{l}\text { Deepening the thoughts beyond the scope of the } \\
\text { auditing profession }\end{array}$ & & & & & & & \\
\hline & $\begin{array}{l}\text { Recognizing the judgment biases in the auditing } \\
\text { profession }\end{array}$ & & & & & & & \\
\hline & Looking ahead when making decisions & & & & & & & \\
\hline & $\begin{array}{l}\text { Breaking the subjective reference frameworks to } \\
\text { achieve professional recognition }\end{array}$ & & & & & & & \\
\hline & $\begin{array}{l}\text { Controlling the emotions when facing } \\
\text { complexities of the auditing profession }\end{array}$ & & & & & & & \\
\hline & $\begin{array}{l}\text { Balanced reliance on insight and intuition in } \\
\text { professional decision-making }\end{array}$ & & & & & & & \\
\hline
\end{tabular}

The Delphi technique is a method of decision-making based on experts' opinions that performed in several rounds reciprocally until theoretical saturation is met wherein the reliability of the themes identified is confirmed. Accordingly, at this stage, the Delphi technique is performed using two criteria, namely, average and concordance coefficient. Table 5 represents the Delphi analysis of the themes identified. 
Table 5. Delphi analysis

\begin{tabular}{|c|c|c|c|c|c|c|}
\hline \begin{tabular}{|c|}
$\begin{array}{c}\text { Organizing } \\
\text { theme } \\
\text { (component) }\end{array}$ \\
\end{tabular} & $\begin{array}{c}\text { Averag } \\
\mathbf{e}\end{array}$ & $\begin{array}{c}\text { Concordan } \\
\text { ce } \\
\text { coefficient }\end{array}$ & Basic themes & Average & \begin{tabular}{|c|}
$\begin{array}{c}\text { Concorda } \\
\text { nce } \\
\text { coefficient }\end{array}$ \\
\end{tabular} & $\begin{array}{l}\text { Accept/ } \\
\text { Remove }\end{array}$ \\
\hline \multirow{8}{*}{$\begin{array}{c}\text { Professional } \\
\text { thinking }\end{array}$} & \multirow{8}{*}{5} & \multirow{8}{*}{0.7} & Learning in the career path & 5.10 & 0.75 & Accepted \\
\hline & & & $\begin{array}{l}\text { Considering the interests of the } \\
\text { majority of the stakeholders }\end{array}$ & 5.20 & 0.8 & Accepted \\
\hline & & & $\begin{array}{l}\text { Evaluating individual abilities in } \\
\text { professional complexities }\end{array}$ & 5 & 0.7 & Accepted \\
\hline & & & $\begin{array}{l}\text { Evaluating the values of the } \\
\text { auditing profession }\end{array}$ & 3.50 & 0.30 & $\begin{array}{c}\text { Remove } \\
\mathrm{d}\end{array}$ \\
\hline & & & $\begin{array}{c}\text { Developing individual knowledge in } \\
\text { the career path }\end{array}$ & 4 & 0.45 & $\begin{array}{c}\text { Remove } \\
\mathrm{d}\end{array}$ \\
\hline & & & $\begin{array}{c}\text { Creating a congruence between } \\
\text { subjectivity and professional } \\
\text { performance }\end{array}$ & 5 & 0.7 & Accepted \\
\hline & & & Having inferential interpretations & 5.10 & 0.75 & Accepted \\
\hline & & & Committing to professional ethics & 5 & 0.7 & Accepted \\
\hline \multirow{5}{*}{$\begin{array}{c}\text { Social } \\
\text { thinking }\end{array}$} & \multirow{5}{*}{5.15} & \multirow{5}{*}{0.78} & $\begin{array}{c}\text { Focusing on social and responsive } \\
\text { approaches related to society }\end{array}$ & 4 & 0.45 & $\begin{array}{c}\begin{array}{c}\text { Remove } \\
\mathrm{d}\end{array} \\
\end{array}$ \\
\hline & & & $\begin{array}{c}\text { Moving in line with regulations and } \\
\text { standards defined }\end{array}$ & 5 & 0.71 & Accepted \\
\hline & & & $\begin{array}{c}\text { Respecting qualitative elements } \\
\text { such as uncertainty and neutrality in } \\
\text { the auditing profession }\end{array}$ & 5.10 & 0.75 & Accepted \\
\hline & & & Respecting fairness and justice & 3 & 0.25 & \begin{tabular}{|c|}
$\begin{array}{c}\text { Remove } \\
\mathrm{d}\end{array}$ \\
\end{tabular} \\
\hline & & & Responsiveness and sobriety & 6 & 0.9 & Accepted \\
\hline \multirow{7}{*}{$\begin{array}{l}\text { Cognitive } \\
\text { thinking }\end{array}$} & \multirow{7}{*}{5.70} & \multirow{7}{*}{0.86} & $\begin{array}{l}\text { Recognizing the special features of } \\
\text { the capital market (such as culture } \\
\text { and the type of industry) }\end{array}$ & 4 & 0.45 & $\begin{array}{c}\text { Remove } \\
\mathrm{d}\end{array}$ \\
\hline & & & \begin{tabular}{|c|}
$\begin{array}{c}\text { Deepening the thoughts beyond the } \\
\text { scope of the auditing profession }\end{array}$ \\
\end{tabular} & 5 & 0.7 & Accepted \\
\hline & & & $\begin{array}{c}\text { Recognizing the judgment biases in } \\
\text { the auditing profession }\end{array}$ & 5.50 & 0.88 & Accepted \\
\hline & & & $\begin{array}{c}\text { Looking ahead when making } \\
\text { decisions }\end{array}$ & 3 & 0.25 & $\begin{array}{c}\text { Remove } \\
\mathrm{d}\end{array}$ \\
\hline & & & $\begin{array}{c}\text { Breaking the subjective reference } \\
\text { frameworks to achieve professional } \\
\text { recognition } \\
\end{array}$ & 6 & 0.9 & Accepted \\
\hline & & & $\begin{array}{c}\text { Controlling the emotions when } \\
\text { facing complexities of the auditing } \\
\text { profession }\end{array}$ & 5.20 & 0.8 & Accepted \\
\hline & & & $\begin{array}{l}\text { Balanced reliance on insight and } \\
\text { intuition in professional decision- } \\
\text { making }\end{array}$ & 5.80 & 0.86 & Accepted \\
\hline
\end{tabular}

In the analysis of Table 4, since the Likert scale used consists of seven points, the themes whose average are greater than or equal to 5 and their concordance coefficient are greater than or equal to 0.5 are accepted as guided 
by Mohammad beigi et al. (2015), Soleimani and Bashash (2013), Valiyan et al. (2018), and other researches. Six themes are removed because their averages are less than 5, and their concordance coefficient is less than 0.5. These themes are represented in Table 6.

Table 6. Themes removed

\begin{tabular}{|c|c|}
\hline $\begin{array}{c}\text { Organizing theme } \\
\text { (component) }\end{array}$ & Basic themes \\
\hline \multirow{2}{*}{ Professional thinking } & Evaluating the values of the auditing profession \\
\cline { 2 - 2 } Social thinking & Developing individual knowledge in the career path \\
\cline { 2 - 2 } Cognitive thinking & Focusing on social and responsive approaches related to society \\
\cline { 2 - 2 } & \begin{tabular}{c} 
Respecting fairness and justice \\
\cline { 2 - 2 }
\end{tabular} \\
\hline
\end{tabular}

Now, the second round of the Delphi analysis is performed by distributing the revised checklists among experts. In this round, all 14 themes that remained from the first round are accepted. Therefore, in addition to the reliability of the themes selected, the theoretical saturation point for validating the concepts related to the auditor's wise tactfulness in professional judgment is achieved. Accordingly, the model extracted from the meta-analysis and Delphi technique can be drawn as Figure 2 .

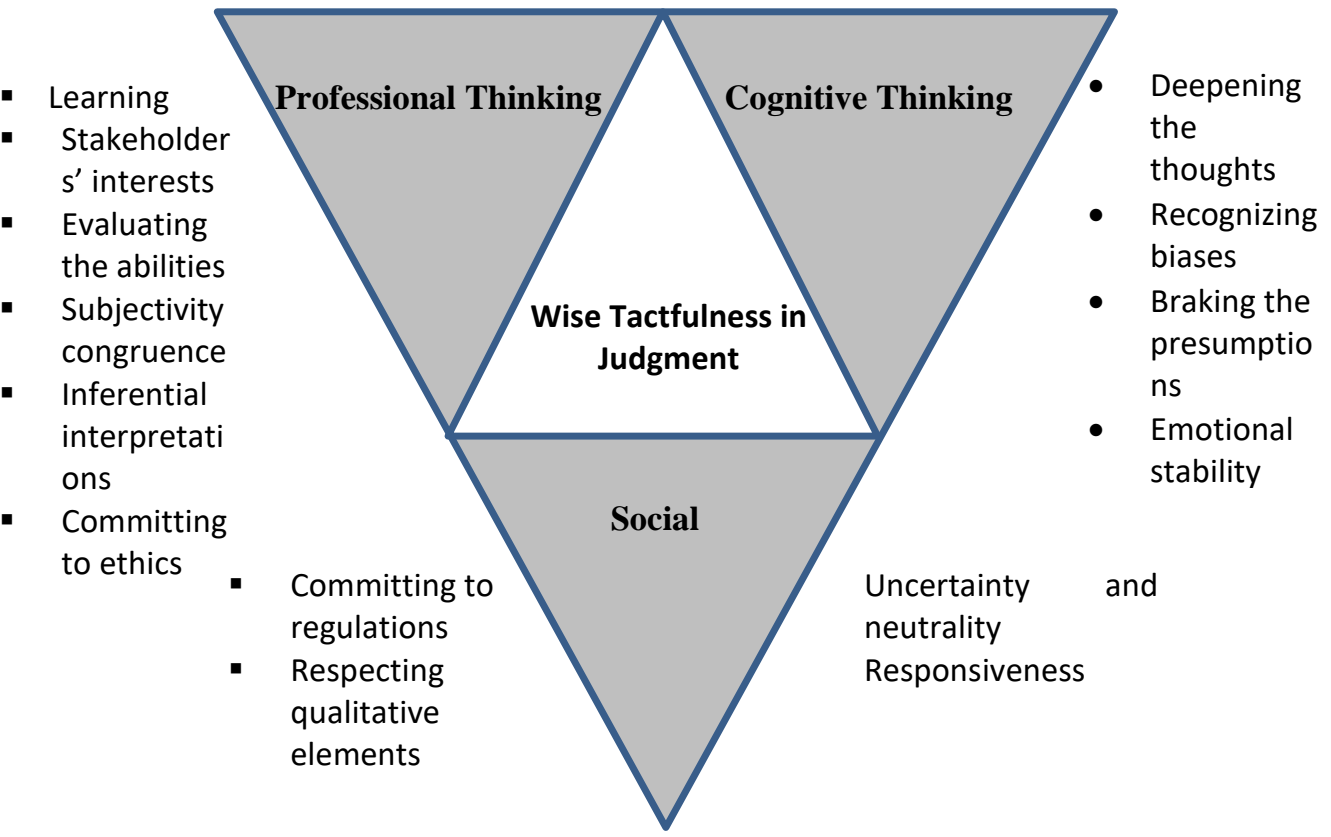

Figure 2. The model of factors of auditor's wise tactfulness in professional judgment 
As seen in Figure 2, wise tactfulness in professional judgment comprises three components, namely, professional, cognitive, and social thinking, which are measured through the themes specified. In other words, the research enters into the phase of Total Interpretive Structural Modeling to determine the hierarchy for prioritizing the themes.

\section{Total Interpretive Structural Modeling (TISM)}

In this phase, the panel members participated, and the scores were determined by the matrix questionnaires. Since TISM is an extended Interpretive structural modeling (ISM) and a more comprehensive method, it can specify the layers of the interactive relationship between the research factors. Figure 3 represents the main steps of TISM.

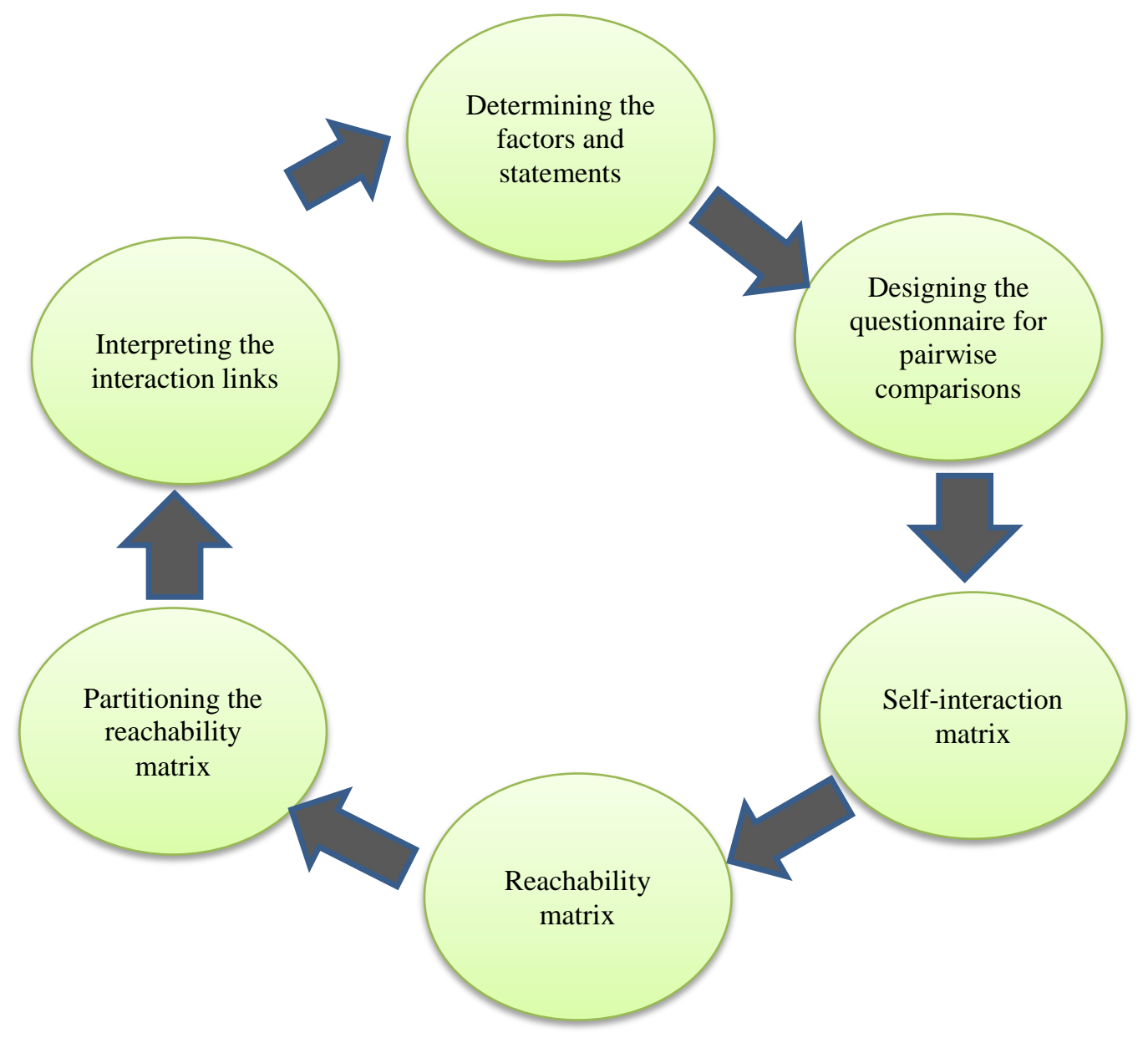

figure 3: The main steps of the TISM process 
The steps represented in Figure 3, which are specific to the themes of wise tactfulness in an auditor's professional judgment, are described as follows.

Step 1: At this step, the themes related to wise tactfulness in auditors' professional judgment are specified based on qualitative approaches such as meta-analysis and Delphi technique (carried out at the first part of research findings)

Step 2: In this step, questionnaires are designed as pairwise comparisons and distributed among the members of the target population to get the selfinteraction matrix. Pairwise comparisons are performed between factors in rows and columns to specify whether the row factor i leads to the factor in column $\mathrm{j}$ or not, and vice versa or the reciprocal relationship exists, or there is no relationship. It also shows the extent of symmetry in relationships between factors.

Step 3: At this step, the self-interaction matrix is built and interpreted. Indeed, pairwise comparisons of the elements are performed with a structural selfinteraction matrix (SSIM) that specifies the only relationship path in Interpretive Structural Modeling (ISM). However, in TISM, each pairwise comparison is interpreted by responding to the interpretive question in the previous step. For pairwise comparison, factor $\mathrm{i}$ is compared with factors (i+1) to $\mathrm{n}$ as paired. For each relationship, the response is specified by a $\mathrm{Y}$ (Yes) or $\mathrm{N}$ (No), and if the response is positive (Y), the reason is stated. In this way, the interpretive rationale of pairwise relationships is presented as a scientific and rational basis of interpretation. Table 7 represented the form used for the pairwise comparison of the factors.

Table 7. A sample form of pairwise comparison based on TISM

\begin{tabular}{|c|l|c|c|}
\hline \multirow{2}{*}{ Factors } & \multicolumn{1}{|c|}{ Question } & Response \\
\cline { 2 - 4 } A1.A2 & $\begin{array}{l}\text { Learning in the career path leads to considering the stakeholders' } \\
\text { interests. }\end{array}$ & $\square$ & No \\
\hline A2.A3 & $\begin{array}{l}\text { Considering the stakeholders' interests shows the level of maturity of } \\
\text { the abilities. }\end{array}$ & $\square$ \\
\hline A1.A3 & $\begin{array}{l}\text { Learning in the career path shows the level of maturity of the abilities. } \\
\text { A3.A4 }\end{array}$ & $\begin{array}{l}\text { Evaluating individual abilities leads to a congruence of the individual's } \\
\text { subjectivities to professional performance. }\end{array}$ & $\square$ \\
\hline A2.A4 & $\begin{array}{l}\text { Considering the stakeholders' interests is a cause for recognizing the } \\
\text { congruence of the individual's subjectivities to professional } \\
\text { performance. }\end{array}$ & $\square$ \\
\hline
\end{tabular}

Note that, due to the restricted number of pages of the paper, only a part of the pairwise comparison form is presented. 
Step 4: At this step, the reachability matrix is obtained using 0 and 1 values by pairwise comparisons conducted by the target population. The relationships used to build the matrix are defined as follows.

If $\mathrm{i}$ leads to $\mathrm{j}$, the $\mathrm{ij}$ element is 1 , and the $\mathrm{ji}$ element is 0 .

If $\mathrm{j}$ leads to $\mathrm{i}$, the $\mathrm{ji}$ element is 0 , and the $\mathrm{ij}$ element is 1 .

If $\mathrm{i}$ is equivalent to $\mathrm{j}$, both the $\mathrm{ij}$ element and $\mathrm{ji}$ element are 1 .

If there is no relationship between $\mathrm{i}$ and $\mathrm{j}$, both the $\mathrm{ij}$ element and $\mathrm{ji}$ element are 0 .

Step 5: At this step, the hierarchical partitioning of the reachability matrix is carried out. To identify the relationship between the variables, first, one should identify the output set, input set, and common elements. The level scores and priorities of the variables are specified using the reachability set and antecedent set. The reachability set for each variable consists of variables that can be reached through the target variable. The antecedent set for each variable also consists of variables through which the target variable can be reached. Then the intersection of the reachability set and antecedent set is obtained for each factor. The factors whose reachability set and antecedent set are the same are considered as the priority level. The level refers to the designed layers of the final model. To obtain the other levels, one should eliminate the previous levels and replicate the process. After the levels are specified, the output matrix should be ordered according to levels. The new matrix is called the conic matrix.

Step 6: At this step, a hierarchical graph is gotten. First, factors of the hierarchical levels are ordered, and then, the relationships between the factors are linked using the reachability matrix.

\section{Analysis of the findings}

Interpretive Structural Analysis (ISM/TISM)

To conduct the analysis, we should first code the factors accepted by the Delphi technique.

Table 8. Coding of the statements accepted

\begin{tabular}{|l|l|}
\hline Factor & Code \\
\hline Learning & A1 \\
\hline Stakeholders' interests & A2 \\
\hline Evaluating individual abilities & A3 \\
\hline Creating a congruence between subjectivities and professional performance & A4 \\
\hline Having inferential interpretations & A5 \\
\hline Committing to professional ethics & A6 \\
\hline Observing the standards & A7 \\
\hline Uncertainty and neutrality & A8 \\
\hline Responsiveness and sobriety & A9 \\
\hline Forethought & A10 \\
\hline Recognizing the perceptual faults & A11 \\
\hline Breaking subjective reference frameworks & A12 \\
\hline Emotional stability & A13 \\
\hline Insight and intuition & A14 \\
\hline
\end{tabular}


As seen in Table 8, the factors accepted by the experts have been coded to build the structural self-interaction matrix. To develop the ISM approach to the TISM approach, we should interpret each paired comparison with responding to the interpretive question in the previous step. Each factor, say i, is compared with all elements from (i+1) to $\mathrm{n}$. For each relationship, the response is a $\mathrm{Y}$ or $\mathrm{N}$, and if the response is positive, the reason should be stated. However, if the response is negative, the participants should declare their opinions about the corresponding variables.

Table 9. Pairwise comparisons between the statements in matrix form

\begin{tabular}{|c|c|c|c|}
\hline No. & Pair & Yes/No & Relationship \\
\hline 1 & $\mathrm{~A} 1-\mathrm{A} 2 *$ & Yes $\boldsymbol{\otimes}$ No $\square$ & $\begin{array}{c}\begin{array}{c}\text { Learning in the career path leads to considering the stakeholders' } \\
\text { interests. }\end{array}\end{array}$ \\
\hline 2 & A2-A1 & Yes $\square$ No $\boldsymbol{x}$ & \\
\hline 3 & A1-A3 & Yes $\square$ No $\boldsymbol{x}$ & \\
\hline 4 & A3-A1 & Yes $\square$ No $\boldsymbol{x}$ & \\
\hline 5 & A1-A4 & Yes $\boldsymbol{~ N o ~} \square$ & \\
\hline 6 & A4-A1 & Yes $\square$ No $\boldsymbol{~}$ & \\
\hline 7 & A1-A5 & Yes $\square$ No $\square$ & $\begin{array}{c}\text { Learning in the career path helps to interpret inferential } \\
\text { interpretations. }\end{array}$ \\
\hline 8 & A5-A1 & Yes $\square$ No $囚$ & \\
\hline 9 & A1-A6 & Yes $\boldsymbol{~ N o ~} \square$ & $\begin{array}{c}\text { Learning in the career path leads to a commitment to professional } \\
\text { ethics. }\end{array}$ \\
\hline 10 & A6-A1 & Yes $\square$ No $囚$ & \\
\hline 11 & A1-A7 & Yes $\boldsymbol{~ N o ~} \square$ & Learning in the career path leads to observing the standards. \\
\hline 12 & A7-A1 & Yes $\square$ No $\mathbf{x}$ & \\
\hline 13 & A1-A8 & Yes $\boldsymbol{x}$ No $\square$ & Learning in the career path fosters uncertainty and neutrality. \\
\hline 14 & A8-A1 & Yes $\square$ No $\boldsymbol{\nabla}$ & \\
\hline 15 & A1-A9 & Yes $囚$ No $\square$ & Learning in the career path increases responsiveness and sobriety. \\
\hline 16 & A9-A1 & Yes $\square$ No $\boldsymbol{x}$ & \\
\hline 17 & $\mathrm{~A} 1-\mathrm{A} 10$ & Yes $\square$ No 冈 & \\
\hline 18 & A10-A1 & Yes $\square$ No $\boldsymbol{~}$ & \\
\hline 19 & $\mathrm{~A} 1-\mathrm{A} 11$ & Yes $\square$ No $\boldsymbol{~}$ & \\
\hline 20 & A11-A1 & Yes $\square$ No 凶 & \\
\hline 21 & A1-A12 & Yes $囚$ No $\square$ & $\begin{array}{l}\text { Learning in the career path leads to breaking the presumed } \\
\text { frameworks. }\end{array}$ \\
\hline 22 & A12-A1 & Yes $\square$ No $\boldsymbol{x}$ & \\
\hline 23 & A1-A13 & Yes $囚$ No $\square$ & Learning in the career path leads to emotional stability. \\
\hline 24 & A13-A1 & Yes $\square$ No $\boldsymbol{x}$ & \\
\hline 25 & $\mathrm{~A} 1-\mathrm{A} 14$ & Yes $囚$ No $\square$ & Learning in the career path fortifies insight and intuition. \\
\hline 26 & A14-A1 & Yes $\square$ No 冈 & \\
\hline
\end{tabular}

Note that due to the restriction on the number of pages of the paper, only some of the pairwise comparisons were presented.

The pairwise comparisons of auditor's wise tactfulness in professional judgment are given in Table (10) to obtain the structural self-interaction matrix 
(SSIM). For pairwise comparison, factor $i$ is compared with factors $(i+1)$ to $n$ as paired. For each relationship, the response is specified by a $\mathrm{Y}$ (Yes) or $\mathrm{N}$ (No), and if the response is positive (Y), the reason is stated. In this way, the interpretive rationale of pairwise relationships is presented as a scientific and rational basis of interpretation.

\section{Phase 3: Building the reachability matrix}

At this phase, relations between the variables turn into 0 or 1 entries in such a way that cells marked with $\mathrm{Y}$ take a value of 1 , and those marked with $\mathrm{N}$ take a value of 0 . Indeed, the reachability matrix is obtained by converting the structural self-interaction matrix into a matrix with binary entries. The matrix is given in Table 10.

Table 10. The reachability matrix

\begin{tabular}{|c|c|c|c|c|c|c|c|c|c|c|c|c|c|c|}
\hline Factors & A1 & A2 & A3 & A4 & A5 & A6 & A7 & A8 & A9 & A10 & A11 & A12 & A13 & A14 \\
\hline A1 & 1 & 0 & 1 & 1 & 1 & 0 & 1 & 1 & 1 & 1 & 1 & 1 & 1 & 1 \\
\hline A2 & 1 & 1 & 1 & 1 & 1 & 0 & 1 & 1 & 1 & 1 & 1 & 1 & 1 & 1 \\
\hline A3 & 0 & 0 & 1 & 1 & 1 & 0 & 1 & 1 & 1 & 1 & 1 & 1 & 1 & 1 \\
\hline A4 & 0 & 0 & 0 & 1 & 1 & 0 & 1 & 1 & 1 & 1 & 1 & 1 & 1 & 1 \\
\hline A5 & 0 & 0 & 0 & 0 & 1 & 0 & 1 & 1 & 1 & 1 & 1 & 1 & 1 & 1 \\
\hline A6 & 1 & 1 & 1 & 1 & 1 & 1 & 1 & 1 & 1 & 1 & 1 & 1 & 1 & 1 \\
\hline A7 & 0 & 0 & 0 & 0 & 0 & 0 & 1 & 1 & 1 & 1 & 1 & 1 & 1 & 1 \\
\hline A8 & 0 & 0 & 0 & 0 & 0 & 0 & 0 & 1 & 1 & 1 & 1 & 1 & 1 & 1 \\
\hline A9 & 0 & 0 & 0 & 0 & 0 & 0 & 0 & 0 & 1 & 1 & 1 & 1 & 1 & 1 \\
\hline A10 & 0 & 0 & 0 & 0 & 0 & 0 & 0 & 0 & 0 & 1 & 1 & 1 & 1 & 1 \\
\hline A11 & 0 & 0 & 0 & 0 & 0 & 0 & 0 & 0 & 0 & 0 & 1 & 1 & 1 & 1 \\
\hline A12 & 0 & 0 & 0 & 0 & 0 & 0 & 0 & 0 & 0 & 0 & 1 & 1 & 1 & 1 \\
\hline A13 & 0 & 0 & 0 & 0 & 0 & 0 & 0 & 0 & 0 & 0 & 1 & 1 & 1 & 1 \\
\hline A14 & 0 & 0 & 0 & 0 & 0 & 0 & 0 & 0 & 0 & 0 & 0 & 0 & 0 & 1 \\
\hline
\end{tabular}

Next, the scores are obtained based on the interaction between the factors compared to build a transitive reachability matrix.

Table 11. The transitivity of the relationships between the factors

\begin{tabular}{|c|c|c|c|c|c|c|c|c|c|c|c|c|c|c|c|}
\hline Factors & A1 & A2 & A3 & A4 & A5 & A6 & A7 & A8 & A9 & A10 & A11 & A12 & A13 & A14 $\begin{array}{c}\text { Drivin } \\
\text { g } \\
\text { power }\end{array}$ \\
\hline A1 & 1 & 0 & 1 & 1 & 1 & 0 & 1 & 1 & 1 & 1 & 1 & 1 & 1 & 1 & 12 \\
\hline A2 & 1 & 1 & 1 & $1^{*}$ & 1 & 0 & 1 & $1^{*}$ & $1^{*}$ & 1 & 1 & 1 & 1 & 1 & 13 \\
\hline A3 & 0 & 0 & 1 & 1 & 1 & 0 & 1 & 1 & 1 & 1 & 1 & 1 & 1 & 1 & 11 \\
\hline A4 & 0 & 0 & 0 & 1 & 1 & 0 & $1^{*}$ & 1 & 1 & 1 & 1 & 1 & $1^{*}$ & 1 & 10 \\
\hline A5 & 0 & 0 & 0 & 0 & 1 & 0 & 1 & 1 & 1 & 1 & 1 & 1 & 1 & 1 & 9 \\
\hline A6 & 1 & 1 & 1 & 1 & 1 & 1 & 1 & 1 & 1 & 1 & 1 & $1 *$ & 1 & 1 & 14 \\
\hline A7 & 0 & 0 & 0 & 0 & 0 & 0 & 1 & 1 & 1 & 1 & 1 & 1 & 1 & 1 & 8 \\
\hline A8 & 0 & 0 & 0 & 0 & 0 & 0 & 0 & 1 & 1 & 1 & 1 & 1 & 1 & 1 & 7 \\
\hline A9 & 0 & 0 & 0 & 0 & 0 & 0 & 0 & 0 & 1 & 1 & 1 & 1 & 1 & 1 & 6 \\
\hline
\end{tabular}


114】 Iranian Journal of Finance, 2021, Vol. 5, No. 2 (Malekipour, F.)

\begin{tabular}{|c|c|c|c|c|c|c|c|c|c|c|c|c|c|c|c|}
\hline A10 & 0 & 0 & 0 & 0 & 0 & 0 & 0 & 0 & 0 & 1 & 1 & 1 & 1 & 1 & 5 \\
\hline A11 & 0 & 0 & 0 & 0 & 0 & 0 & 0 & 0 & 0 & 0 & 1 & 1 & 1 & $1 *$ & 4 \\
\hline A12 & 0 & 0 & 0 & 0 & 0 & 0 & 0 & 0 & 0 & 0 & 1 & 1 & 1 & 1 & 4 \\
\hline A13 & 0 & 0 & 0 & 0 & 0 & 0 & 0 & 0 & 0 & 0 & 1 & 1 & 1 & 1 & 4 \\
\hline A14 & 0 & 0 & 0 & 0 & 0 & 0 & 0 & 0 & 0 & 0 & 0 & 0 & 0 & 1 & 1 \\
\hline $\begin{array}{c}\text { Dependen } \\
\text { ce } \\
\text { power }\end{array}$ & 3 & 2 & 4 & 5 & 6 & 1 & 7 & 8 & 9 & 10 & 13 & 13 & 13 & 14 & \\
\hline
\end{tabular}

As seen in table 11, conceptual notations assigned based on the mode criterion have been converted into the values 0,1 , and $1^{*}$, according to the definitions given. Table 11 shows the driving power (total 1 scores in the corresponding row) and dependence power (total 1 scores in the corresponding column).

Table 12. Driving power/Dependence power

\begin{tabular}{|c|c|c|c|}
\hline Factor & Code & $\begin{array}{c}\text { Driving } \\
\text { power }\end{array}$ & $\begin{array}{c}\text { Dependence } \\
\text { power }\end{array}$ \\
\hline Learning & A1 & 12 & 3 \\
\hline Stakeholders' interests & A2 & 13 & 2 \\
\hline Evaluating individual abilities & A3 & 11 & 4 \\
\hline $\begin{array}{c}\text { Congruency between subjectivities and professional } \\
\text { performance }\end{array}$ & A4 & 10 & 5 \\
\hline Having inferential interpretations & A5 & 9 & 6 \\
\hline Commitment to professional ethics & A6 & 14 & 1 \\
\hline Observing the standards & A7 & 8 & 7 \\
\hline Uncertainty and neutrality & A8 & 7 & 8 \\
\hline Responsiveness and sobriety & A9 & 6 & 9 \\
\hline Forethought & A10 & 5 & 10 \\
\hline Recognizing the perceptual faults & A11 & 4 & 13 \\
\hline Breaking the subjective reference frameworks & A12 & 4 & 13 \\
\hline Emotional stability & A13 & 4 & 13 \\
\hline Insight and intuition & A14 & 1 & 14 \\
\hline
\end{tabular}

Determining the relationships between the variables and building the conic matrix

In this section, first, the output set, input set, and common elements should be identified to determine the relationship between the variables. The level scores and priorities of the variables, as well as the reachability set and antecedent set, are obtained. The reachability set for each variable consists of variables that can be reached through the target variable. The antecedent set for each variable also consists of variables through which the target variable can be reached. Then, the intersection of the reachability set and antecedent set is obtained for each factor. The factors with the same reachability set and antecedent set are 
considered as the priority level. The level refers to the designed layers of the final model. To obtain the other levels, one should eliminate the previous levels and iterate the process. After the levels are specified, the output matrix should be ordered according to levels. The new matrix is called the conic matrix.

\section{Level partitioning}

At this stage, the input set and output set are obtained for each variable through the final reachability matrix. The output set for a component/dimension is consists of the variable itself along with other variables that affected by it, i.e., the variables that can be reached through the target variable. The input set for each variable also includes the variable itself along with the variables that affect the target variable. Finally, the common elements as the high-level variables refer to the dimensions belonging to the intersection between the output set and input set in the TISM process, i.e., those variables that do not affect any other variable. After input elements, output elements, and common elements are determined, factors that have the same output elements and common elements are known as the first level and most ineffective outcome of internal auditing effectiveness. After determining this level, the corresponding factors are eliminated, and the common elements between the input set and output set are specified and selected as the next level. This process is replicated until the components constituted all the levels of the system are specified.

Table 13. The output set, input set, and common elements

\begin{tabular}{|c|c|c|c|c|c|}
\hline Factor & Code & Output factor & Input factor & Intersection & Level \\
\hline \multicolumn{6}{|c|}{ + Determining the first level } \\
\hline Learning & A1 & $\begin{array}{l}1,3,4,5,7,8 \\
9,10,11,12 \\
13,14\end{array}$ & $1,2,6$ & 1 & \\
\hline Stakeholders' interests & $\mathrm{A} 2$ & $\begin{array}{c}1,2,3,4,5,7 \\
8,9,10,11 \\
12,13,14\end{array}$ & 2,6 & 2 & \\
\hline Evaluating individual abilities & A3 & $\begin{array}{c}3,4,5,7,8,9 \\
10,11,12,13 \\
14\end{array}$ & $1,2,3,6$ & 3 & \\
\hline $\begin{array}{c}\text { Creating a congruence between } \\
\text { subjectivities and professional } \\
\text { performance }\end{array}$ & A4 & $\begin{array}{c}4,5,7,8,9 \\
10,11,12,13 \\
14\end{array}$ & $1,2,3,4,6$ & 4 & \\
\hline $\begin{array}{c}\text { Having inferential } \\
\text { interpretations }\end{array}$ & A5 & $\begin{array}{l}5,7,8,9,10 \\
11,12,13,14\end{array}$ & $1,2,3,4,5,6$ & 5 & \\
\hline $\begin{array}{c}\text { Committing to professional } \\
\text { ethics }\end{array}$ & A6 & $\begin{array}{c}1,2,3,4,5,7 \\
8,9,10,11 \\
12,13,14 \\
\end{array}$ & 6 & 6 & \\
\hline Observing the standards & A7 & $\begin{array}{c}7,8,9,10,11 \\
12,13,14\end{array}$ & $\begin{array}{c}1,2,3,4,5,6 \\
7\end{array}$ & 7 & \\
\hline
\end{tabular}


116 Iranian Journal of Finance, 2021, Vol. 5, No. 2 (Malekipour, F.)

\begin{tabular}{|c|c|c|c|c|c|}
\hline Uncertainty and neutrality & A8 & $\begin{array}{c}8,9,10,11 \\
12,13,14 \\
\end{array}$ & $\begin{array}{c}1,2,3,4,5,6 \\
7,8\end{array}$ & 8 & \\
\hline Responsiveness and sobriety & A9 & $\begin{array}{c}9,10,11,12 \\
13,14\end{array}$ & $\begin{array}{c}1,2,3,4,5,6 \\
7,8,9\end{array}$ & 9 & \\
\hline Forethought & A10 & $\begin{array}{c}10,11,12,13 \\
14\end{array}$ & $\begin{array}{c}1,2,3,4,5,6 \\
7,8,9,10\end{array}$ & 10 & \\
\hline $\begin{array}{l}\text { Recognizing the perceptual } \\
\text { faults }\end{array}$ & A11 & $11,12,13,14$ & $\begin{array}{c}1,2,3,4,5,7 \\
8,9,10,11 \\
12,13 \\
\end{array}$ & $\begin{array}{c}11,12,13 \\
14\end{array}$ & \\
\hline $\begin{array}{l}\text { Breaking subjective reference } \\
\text { frameworks }\end{array}$ & A12 & $11,12,13,14$ & $\begin{array}{c}1,2,3,4,5,7 \\
8,9,10,11 \\
12,13 \\
\end{array}$ & $\begin{array}{c}11,12,13, \\
14\end{array}$ & \\
\hline Emotional stability & A13 & $11,12,13,14$ & $\begin{array}{c}1,2,3,4,5,7 \\
8,9,10,11 \\
12,13\end{array}$ & $\begin{array}{c}11,12,13 \\
14\end{array}$ & \\
\hline Insight and intuition & A14 & 14 & $\begin{array}{c}1,2,3,4,5,7 \\
8,9,10,11 \\
12,13,14 \\
\end{array}$ & 14 & I \\
\hline Factor & Code & Output factor & Input factor & Intersection & Level \\
\hline \multicolumn{6}{|c|}{ + Determining the second level } \\
\hline Learning & A1 & $\begin{array}{l}1,3,4,5,7,8 \\
9,10,11,12 \\
13\end{array}$ & $1,2,6$ & 1 & \\
\hline Stakeholders' interests & $\mathrm{A} 2$ & $\begin{array}{c}1,2,3,4,5,7 \\
8,9,10,11 \\
12,13\end{array}$ & 2,6 & 2 & \\
\hline Evaluating individual abilities & A3 & $\begin{array}{c}3,4,5,7,8,9 \\
10,11,12,13 \\
\end{array}$ & $1,2,3,6$ & 3 & \\
\hline $\begin{array}{c}\text { Creating a congruence between } \\
\text { subjectivities and professional } \\
\text { performance }\end{array}$ & A4 & $\begin{array}{c}4,5,7,8,9 \\
10,11,12,13\end{array}$ & $1,2,3,4,6$ & 4 & \\
\hline $\begin{array}{c}\text { Having inferential } \\
\text { interpretations }\end{array}$ & A5 & $\begin{array}{c}5,7,8,9,10 \\
11,12,13 \\
\end{array}$ & $1,2,3,4,5,6$ & 5 & \\
\hline $\begin{array}{l}\text { Committing to professional } \\
\text { ethics }\end{array}$ & A6 & $\begin{array}{c}1,2,3,4,5,7 \\
8,9,10,11 \\
12,13 \\
\end{array}$ & 6 & 6 & \\
\hline Observing the standards & A7 & $\begin{array}{c}7,8,9,10,11 \\
12,13 \\
\end{array}$ & $\begin{array}{c}1,2,3,4,5 \\
6,7 \\
\end{array}$ & 7 & \\
\hline Uncertainty and neutrality & A8 & $\begin{array}{c}8,9,10,11 \\
12,13\end{array}$ & $\begin{array}{c}1,2,3,4,5,6 \\
7,8\end{array}$ & 8 & \\
\hline Responsiveness and sobriety & A9 & $\begin{array}{c}9,10,11,12 \\
13 \\
\end{array}$ & $\begin{array}{c}1,2,3,4,5,6 \\
7,8,9\end{array}$ & 9 & \\
\hline Forethought & A10 & $10,11,12,13$ & $\begin{array}{c}1,2,3,4,5,6 \\
7,7,8,9,10 \\
\end{array}$ & 10 & \\
\hline $\begin{array}{l}\text { Recognizing the perceptual } \\
\text { faults }\end{array}$ & A11 & $11,12,13$ & $\begin{array}{c}1,2,3,4,5,7 \\
8,9,10,11 \\
12,13 \\
\end{array}$ & $11,12,13$ & II \\
\hline Breaking subjective reference & A12 & $11,12,13$ & $1,2,3,4,5,7$ & $11,12,13$ & II \\
\hline
\end{tabular}




\begin{tabular}{|c|c|c|c|c|c|}
\hline frameworks & & & $\begin{array}{c}8,9,10,11 \\
12,13\end{array}$ & & \\
\hline Emotional stability & A13 & $11,12,13$ & $\begin{array}{c}1,2,3,4,5,7 \\
8,9,10,11 \\
12,13 \\
\end{array}$ & $11,12,13$ & II \\
\hline Factor & Code & Output factor & Input factor & Intersection & Level \\
\hline \multicolumn{6}{|c|}{ + Determining the third level } \\
\hline Learning & A1 & $\begin{array}{c}1,3,4,5,7,8 \\
9,10\end{array}$ & $1,2,6$ & 1 & \\
\hline Stakeholders' interests & $\mathrm{A} 2$ & $\begin{array}{c}1,2,3,4,5,7 \\
8,9,10\end{array}$ & 2,6 & 2 & \\
\hline Evaluating individual abilities & A3 & $\begin{array}{c}3,4,5,7,8,9 \\
10\end{array}$ & $1,2,3,6$ & 3 & \\
\hline $\begin{array}{c}\text { Creating a congruence between } \\
\text { subjectivities and professional } \\
\text { performance }\end{array}$ & A4 & $4,5,7,8,9,10$ & $1,2,3,4,6$ & 4 & \\
\hline $\begin{array}{l}\text { Having inferential } \\
\text { interpretations }\end{array}$ & A5 & $5,7,8,9,10$ & $1,2,3,4,5,6$ & 5 & \\
\hline $\begin{array}{l}\text { Committing to professional } \\
\text { ethics }\end{array}$ & A6 & $\begin{array}{c}1,2,3,4,5,7 \\
8,9,10\end{array}$ & 6 & 6 & \\
\hline Observing the standards & A7 & $7,8,9,10$ & $\begin{array}{c}1,2,3,4,5,6 \\
7\end{array}$ & 7 & \\
\hline Uncertainty and neutrality & A8 & $8,9,10$ & $\begin{array}{c}1,2,3,4,5,6 \\
7,8\end{array}$ & 8 & \\
\hline Responsiveness and sobriety & A9 & 9,10 & $\begin{array}{c}1,2,3,4,5,6 \\
7,8,9 \\
\end{array}$ & 9 & \\
\hline Forethought & A10 & 10 & $\begin{array}{c}1,2,3,4,5,6 \\
7,8,9,10\end{array}$ & 10 & III \\
\hline Factor & Code & Output factor & Input factor & Intersection & Level \\
\hline \multicolumn{6}{|c|}{+ Determining the fourth level } \\
\hline Learning & A1 & $\begin{array}{c}1,3,4,5,7,8 \\
9\end{array}$ & $1,2,6$ & 1 & \\
\hline Stakeholders' interests & A2 & $\begin{array}{c}1,2,3,4,5,7 \\
8,9\end{array}$ & 2,6 & 2 & \\
\hline Evaluating individual abilities & A3 & $3,4,5,7,8,9$ & $1,2,3,6$ & 3 & \\
\hline $\begin{array}{l}\text { Creating a congruence between } \\
\text { subjectivities and professional } \\
\text { performance }\end{array}$ & A4 & $4,5,7,8,9$ & $1,2,3,4,6$ & 4 & \\
\hline $\begin{array}{l}\text { Having inferential } \\
\text { interpretations }\end{array}$ & A5 & $5,7,8,9$ & $1,2,3,4,5,6$ & 5 & \\
\hline $\begin{array}{c}\text { Committing to professional } \\
\text { ethics }\end{array}$ & A6 & $\begin{array}{c}1,2,3,4,5,7 \\
8,9 \\
\end{array}$ & 6 & 6 & \\
\hline Observing the standards & A7 & $7,8,9$ & $\begin{array}{c}1,2,3,4,5,6 \\
7\end{array}$ & 7 & \\
\hline Uncertainty and neutrality & A8 & 8,9 & $\begin{array}{c}1,2,3,4,5,6 \\
7,8 \\
\end{array}$ & 8 & \\
\hline Responsiveness and sobriety & A9 & 9 & $1,2,3,4,5,6$ & 9 & IV \\
\hline
\end{tabular}


Iranian Journal of Finance, 2021, Vol. 5, No. 2 (Malekipour, F.)

\begin{tabular}{|c|c|c|c|c|c|}
\hline & & & $7,8,9$ & & \\
\hline Factor & Code & Output factor & Input factor & Intersection & Level \\
\hline \multicolumn{6}{|c|}{ + Determining the fifth level } \\
\hline Learning & A1 & $1,3,4,5,7,8$ & $1,2,6$ & 1 & \\
\hline Stakeholders' interests & $\mathrm{A} 2$ & $\begin{array}{c}1,2,3,4,5,7 \\
8\end{array}$ & 2,6 & 2 & \\
\hline Evaluating individual abilities & A3 & $3,4,5,7,8$ & $1,2,3,6$ & 3 & \\
\hline $\begin{array}{c}\text { Creating a congruence between } \\
\text { subjectivities and professional } \\
\text { performance }\end{array}$ & A4 & $4,5,7,8$ & $1,2,3,4,6$ & 4 & \\
\hline $\begin{array}{l}\text { Having inferential } \\
\text { interpretations }\end{array}$ & A5 & $5,7,8$ & $1,2,3,4,5,6$ & 5 & \\
\hline $\begin{array}{l}\text { Committing to professional } \\
\text { ethics }\end{array}$ & A6 & $\begin{array}{c}1,2,3,4,5,7 \\
8\end{array}$ & 6 & 6 & \\
\hline Observing the standards & A7 & 7,8 & $\begin{array}{c}1,2,3,4,5,6, \\
7\end{array}$ & 7 & \\
\hline Uncertainty and neutrality & A8 & 8 & $\begin{array}{c}1,2,3,4,5,6 \\
7,8 \\
\end{array}$ & 8 & V \\
\hline Factor & Code & Output factor & Input factor & Intersection & Level \\
\hline \multicolumn{6}{|c|}{ + Determining the sixth level } \\
\hline Learning & A1 & $1,3,4,5,7$ & $1,2,6$ & 1 & \\
\hline Stakeholders' interests & $\mathrm{A} 2$ & $1,2,3,4,5,7$ & 2,6 & 2 & \\
\hline Evaluating individual abilities & A3 & $3,4,5,7$ & $1,2,3,6$ & 3 & \\
\hline $\begin{array}{c}\text { Creating a congruence between } \\
\text { subjectivities and professional } \\
\text { performance }\end{array}$ & A4 & $4,5,7$ & $1,2,3,4,6$ & 4 & \\
\hline $\begin{array}{l}\text { Having inferential } \\
\text { interpretations }\end{array}$ & A5 & 5,7 & $1,2,3,4,5,6$ & 5 & \\
\hline $\begin{array}{l}\text { Committing to professional } \\
\text { ethics }\end{array}$ & A6 & $1,2,3,4,5,7$ & 6 & 6 & \\
\hline Observing the standards & A7 & 7 & $\begin{array}{c}1,2,3,4,5,6, \\
7\end{array}$ & 7 & VI \\
\hline Factor & Code & Output factor & Input factor & Intersection & Level \\
\hline \multicolumn{6}{|c|}{ + Determining the seventh level } \\
\hline Learning & A1 & $1,3,4,5$ & $1,2,6$ & 1 & \\
\hline Stakeholders' interests & $\mathrm{A} 2$ & $1,2,3,4,5$ & 2,6 & 2 & \\
\hline Evaluating individual abilities & A3 & $3,4,5$ & $1,2,3,6$ & 3 & \\
\hline $\begin{array}{c}\text { Creating a congruence between } \\
\text { subjectivities and professional } \\
\text { performance }\end{array}$ & A4 & 4,5 & $1,2,3,4,6$ & 4 & \\
\hline $\begin{array}{l}\text { Having inferential } \\
\text { interpretations }\end{array}$ & A5 & 5 & $1,2,3,4,5,6$ & 5 & \\
\hline $\begin{array}{c}\text { Committing to professional } \\
\text { ethics }\end{array}$ & A6 & $1,2,3,4,5$ & 6 & 6 & VII \\
\hline Factor & Code & Output factor & Input factor & Intersection & Level \\
\hline
\end{tabular}




\begin{tabular}{|c|c|c|c|c|c|}
\hline \multicolumn{6}{|c|}{ + Determining the eighth level } \\
\hline Learning & A1 & $1,3,4$ & $1,2,6$ & 1 & \\
\hline Stakeholders' interests & A2 & $1,2,3,4$ & 2,6 & 2 & \\
\hline Evaluating individual abilities & A3 & 3,4 & $1,2,3,6$ & 3 & \\
\hline $\begin{array}{l}\text { Creating a congruence between } \\
\text { subjectivities and professional } \\
\text { performance }\end{array}$ & A4 & 4 & $1,2,3,4,6$ & 4 & VIII \\
\hline $\begin{array}{l}\text { Committing to professional } \\
\text { ethics }\end{array}$ & A6 & $1,2,3,4$ & 6 & 6 & \\
\hline Factor & Code & Output factor & Input factor & Intersection & Level \\
\hline \multicolumn{6}{|c|}{ + Determining the ninth level } \\
\hline Learning & A1 & 1,3 & $1,2,6$ & 1 & \\
\hline Stakeholders' interests & A2 & $1,2,3$ & 2,6 & 2 & \\
\hline Evaluating individual abilities & A3 & 3 & $1,2,3,6$ & 3 & IX \\
\hline $\begin{array}{l}\text { Committing to professional } \\
\text { ethics }\end{array}$ & A6 & $1,2,3$ & 6 & 6 & \\
\hline Factor & Code & Output factor & Input factor & Intersection & Level \\
\hline \multicolumn{6}{|c|}{ + Determining the tenth level } \\
\hline Learning & A1 & 1 & $1,2,6$ & 1 & $\bar{X}$ \\
\hline Stakeholders' interests & A2 & 1,2 & 2,6 & 2 & \\
\hline $\begin{array}{l}\text { Committing to professional } \\
\text { ethics }\end{array}$ & A6 & 1,2 & 6 & 6 & \\
\hline Factor & Code & Output factor & Input factor & Intersection & Level \\
\hline \multicolumn{6}{|c|}{ + Determining the eleventh level } \\
\hline Stakeholders' interests & $\mathrm{A} 2$ & 2 & 2,6 & 2 & $\mathrm{XI}$ \\
\hline $\begin{array}{l}\text { Committing to professional } \\
\text { ethics }\end{array}$ & A6 & 2,6 & 6 & & \\
\hline Factor & Code & Output factor & Input factor & Intersection & Level \\
\hline \multicolumn{6}{|c|}{+ Determining the twelfth level } \\
\hline $\begin{array}{c}\text { Committing to professional } \\
\text { ethics }\end{array}$ & A6 & 6 & 6 & 6 & XII \\
\hline
\end{tabular}

As seen in Table 13, the first level, which is the less effective factor of wise tactfulness in auditor's judgment, is insight and intuition in the auditing profession, coded as A14. The last level shows that committing to professional ethics, which was coded as A6, was the most effective factor of auditor's wise tactfulness in professional judgment. Other levels also can be seen in Table 15. 


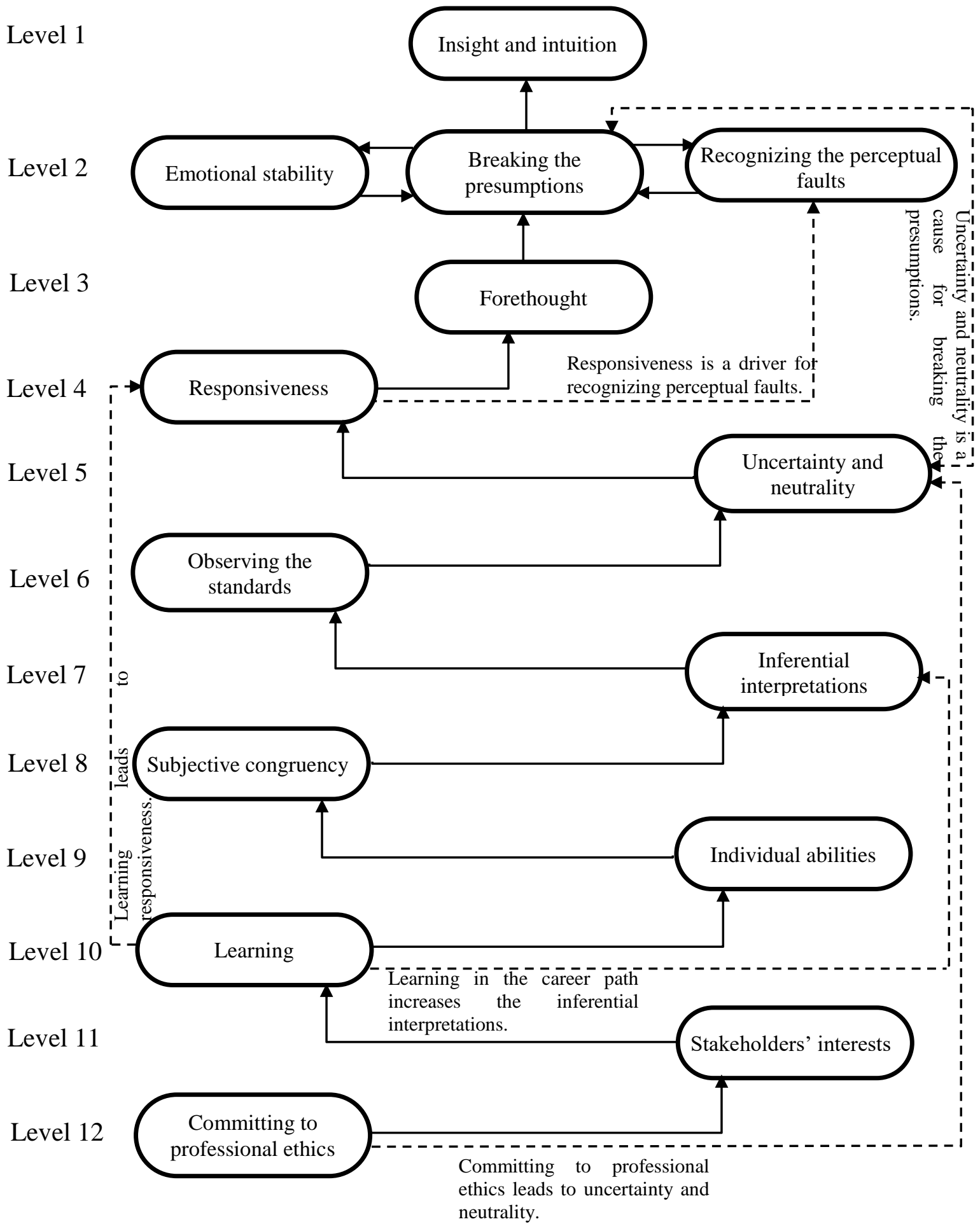

Figure 3. The model of prioritized factors of wise tactfulness in professional auditing 


\section{Conclusion and Suggestions}

Tactfulness, in line with wisdom, is a concept based on an understanding of inferential complexities that involves some aspects of individual knowledge and perception. Since auditors should judge the performance of clients according to inferences and evidence, knowing the components of wise tactfulness as an inferential element in decision-making is important and necessary to decision-making. More clearly, if the auditor achieves a level of wise tactfulness, he/she can better imply from the evidence provided by clients. Indeed, wise tactfulness is a step-by-step process to reach a level of judgment that probably is mixed with the auditor's intuition power and forms the auditor's comments. The purpose of this research was to know the factors of an auditor's tactfulness in professional judgment and prioritizing them based on the importance degree. In this research, first, meta-analysis is applied to identify the themes related to the factors of wise tactfulness. Regarding the lack of relevant research, finally, 12 pieces of research were selected to extract the themes related to the purpose. Then, to validate the researches, we again conducted a critical appraisal of researches found using the panel members based on ten criteria. At this stage, two out of 12 research papers were deleted, and ten pieces of research were accepted. Then, through content analysis and comprehensive review of the texts, the themes of the auditor's wise tactfulness in professional judgment are determined. Consequently, 20 basic themes (factors) in three groups of organizing themes (components) were identified and applied in Delphi analysis to reach a stable level. The analysis removed six basic themes, and 14 themes remained to enter into a Total Interpretive Structural Modeling. At this stage, committing to professional ethics was identified to be the most influential theme of wise tactfulness to increase the quality of professional judgment in auditing. Indeed, regarding the concept of wise tactfulness, the decision-maker (auditor) should commit to the principles of professional ethics free of any dependence to can judge realistically in line with standards of behavioral and performance independence in auditing. Indeed, commitment to ethical principles is one of the behavioral factors in the auditing profession often emphasized along the intellectual decision-making process that shapes the wise decision-making framework. Commitment to professional ethics causes the auditor to think and decide independently of others' influence and power. Furthermore, at the eleventh level, as an impressive level, recognizing the stakeholders' interests and observing their rights was identified to be another important factor affecting the auditor's wise tactfulness in decision-making that makes the auditor as the decision-maker to give priority to stakeholders' interests and to not be enticed with profit-seeking 
temptations by mediators. Considering the stakeholder's interests is a significant factor in presenting wise tactfulness because if the decision-maker does not discriminate between the interest of majority and minority, he/she can better direct realities along a wise path. This principle, as one of the rules of wise decision-making, is not excluded from the auditing profession, and the auditor should be sensitive to other individuals' interests. On the other hand, at the tenth level, learning in the career path was identified as a theme of professional thinking to have a substantial importance in shaping auditor's wise tactfulness. Learning in the career path causes the auditor to acquire abundant experiences and better understand the potential challenges in the professional environment and decide more quickly and reasonably. Indeed, learning has a key role in creating wise tactfulness because it provides a kind of acquisition in the inferential processes of auditor's judgment gradually, and causes that auditors have a better perception of their decision-making and remarks according to the evidence and documents. On the other hand, the ninth level implied that evaluating individual abilities in dealing with complexities of the auditing profession is a theme of professional thinking that plays a considerable role in auditor's wise tactfulness. An auditor possessing the wise tactfulness trait, first, investigates his/her abilities to comment on the performance of clients to decide based on realities. Auditors having wise tactfulness usually first consider their abilities for auditing reviews to be able to carry out their social responsibilities related to stakeholders correctly. At the eighth level, the creation of congruence between subjectivities and professional performance found as a theme of professional thinking. This feature means that an auditor possessing wise tactfulness tries to adjust his/her interpretive subjectivities to performances according to auditing standards, thereby avoiding one-dimensional viewing and dependence on clients, because this issue may severely harm intellectual thought frameworks and lead to a disruption in auditors' professional judgments. At the seventh level of the Total Interpretive Structural Modeling process, the theme inferential interpretations, as the last theme of professional thinking, has relative importance regarding the 12 layers of the thematic influence. In other words, inferential interpretations as a factor of wise tactfulness help the auditor to act related to clients more dominantly with a clear perception of the issue and rational judgment. Inferential interpretations help the auditor to review clients' documents and performance from different perspectives through wise tactfulness and not to comment regarding only a one-dimensional approach without any inference. On the other hand, at the sixth level, the theme of observing the standards (moving in line with regulations and standards set) is a medium-effect theme in wise tactfulness that causes the auditor to adhere to regulations and instructions 
based on which he/she should decide. The results obtained are somewhat consistent with those of Lam and Mensah (2016), Sweeney et al. (2014), and Valiyan et al. (2019) regarding the concepts and theories presented.

Indeed, this research demonstrates that the presumptions of attitude and professional thinking are required to move along wise tactfulness to promote judgment quality because, without a professional attitude that is achieved through experience, he/she cannot decide with a comprehensive approach for audit judgment regarding either the content or performance. An auditor can select true reasons and inferences for decisions resulting in judgment in his/her career path due to observing the professional behavior. Other features such as cognitive and social features, even important, receive less priority regarding the nature of wise features that are based on a step-by-step process to achieve an intellectual decision. Achieving a level of professional judgment that is greatly important in terms of commitment to ethical principles and observance of standards was conformed as a basis for wise tactfulness by the results of this paper. The research implied that the capacity of auditors' effective decisions could be effloresced through integrating wise tactfulness into professional and social attitudes, and cognitive skills, and it may increase the social values and benefits affecting the decisions of shareholders. Although the research is concerned about decisions based on data solely and real evidence, it cannot be noted certainly that wise tactfulness can be institutionalized in auditors, because this work needs continuous learning and acquiring experience from various challenging auditing environments. It is suggested for future research to study how the factors identified can contribute effectively in various environments of the capital market, such as managers' behavioral areas and internal control. Indeed, the current research is one of the first empirical studies in the area of philosophy of auditing career based on wise tactfulness that can greatly help to create high-level viewpoints in auditors' professional judgment. In this way, they avoid deciding based on apparent realities solely and somewhat can benefit from other strengths such as intuition, internal and external searches, emotional stability, and cognitive values to bring more interest for stakeholders. The outcomes of the research also help shareholders to decide on companies' performances with a deeper perception and lead to more attractive investments in the capital market. Auditors' wise tactfulness also, through empowering the interaction of stakeholders with the surrounding environment, extends the role of emotions, intuition, and continuous learning to go beyond technical knowledge. The research is limited, especially because it does not explain the factors of wise tactfulness in the population of auditors engaged in empirical work. This can be recommended for future research. 
Although the components of wise tactfulness in data of the meta-analysis are presented, it is significantly necessary to regard other unknown factors in this area, which are identified only through discussing and interpreting the rationale behind the auditor's professional judgments. This limitation needs further research because researchers who are interested in studying the topic of wise tactfulness are required to identify other dimensions of the concept, such as external dimensions not considered, to generalize the results of this study. Furthermore, the results can be generalized further by conducting quantitative research.

Funding: This research received no external funding.

\section{References}

Andrel, J, A., Keith, S, W., Leiby, B, E. (2009). Meta-analysis: A Brief Introduction, Clinical and Translational Science, 2(5): 374-378.

Attri, r., Dev, n., \& Sharma, v. (2013). Interpretive Structural Modelling (ISM) approach: An Overview. Research Journal of Management Sciences, 2(2), 6.

Azkia M., Tavakkoli, M. (2016). Meta-analysis of researches on job satisfaction in educational organizations, Journal of Social sciences Letters, 27 (2), 1-26. (In Persian).

Baltes, P. B., \& Smith, J. (1990). Toward a psychology of wisdom and its ontogenesis. In R. J. Sternberg (Ed.), Toward a psychology of wisdom and its ontogenesis. New York: Cambridge University Press, 87-120.

Bergsma, A., \& Ardelt, M. (2012). Self-reported wisdom and happiness: An empirical investigation. Journal of Happiness Studies, 13(3), 481-499

Csikszentmihalyi, M., Rathunde, K. (1990). The psychology of wisdom: An evolutionary interpretation, In R. Sternberg (Ed.), Wisdom: Its nature, origins, and development, Cambridge: New York: 25-51

Dunn, J. (2005). Auditing Theory and Practice, Prentice-Hall Direct; Subsequent Second Edition.

Ejabi, E., Ghazi, H., Malekmohammadi, H. (2012). Decision-taking and decision-making through simulation models, Journal of military science and tactics, 8(22), 51-66.

Elangovan, A, R., Suddaby, R. (2018). Solomons for our times: Wisdom in decision-making in organizations, Organizational Dynamics, https://doi.org/10.1016/j.orgdyn.2019.03.001 
Javidi K, Royaei R, Talebnia G, Banimahd B. (2019). Investigating the Effect of Construal Mindset Orientation on Auditors' Judgment and Decision Making: Based on Construal level Theory of Psychological Distance. Quarterly financial accounting journal, 10 (39): 141-169. (In Persian).

Kadous, K., Zhou, Y. (2018). How Does Intrinsic Motivation Improve Auditor Judgment in Complex Audit Tasks?, Contemporary Accounting Research, 36(1): 108131. https://doi.org/10.1111/1911-3846.12431

Lam, K, C, K., Mensah, M. (2016). Auditors' decision-making undergoingconcern uncertainties in low litigation-risk environments: Evidence from Hong Kong, Journal of Accounting and Public Policy 25; 706-739.

Lenz, H. (2008). The Rational Auditor and Moral Norms: The Code of Ethics for Professional Accountants - Lip Service or Self-Binding Agreement? http://dx.doi.org/10.2139/ssrn.2717507

Lynch, A, L., Murthy, U, S., Engle, T, J. (2009) Fraud brainstorming using computer-mediated communication: The effects of brainstorming technique and facilitation. Accounting Review 84(4): 1209-1232.

Malone, D. W. (2014). An introduction to the application of interpretive structural modeling. Proceedings of the IEEE, 63(3), 397-404.

Mashayekhifard S, Pourzamani Z, Jahanshad A. (2019). The Mediating Role of the Auditor's Philosophic-Mindedness on Effects of Social Trust and Social Identity on Professional Judgment, Iranian Journal of Value and Behavioral Accounting, 4 (7), 23-62. (In Persian).

Melé, D. (2010). Practical wisdom in managerial decision making, Journal of Management Development, Vol. 29 Issue: 7/8, pp.637-645, https://doi.org/10.1108/02621711011059068

Mohammadbeigi A, Mohammadsalehi N, Aligol M. (2015). Validity and Reliability of the Instruments and Types of Measurements in Health Applied Researches. Journal of Rafsanjan University of Medical Sciences. 13 (12), 1153-1170. (In Persian).

Paranoan, N., Roreng, P, P., Tandirerung, C, J., Tandungan, E, S. (2018). Disclosing Professionalism Behaviour of Internal Auditor in Preventing Fraud by Using the Local Cultural Wisdom 'Longko' (A Case Study at Toraja Tribe, South Sulawesi, Indonesia), The 2018 International Conference of Organizational Innovation, DOI 10.18502/kss.v3i10.3462

Radcliffe, V, S. (1998). Efficiency audit: An assembly of rationalities and programmes, Accounting, Organizations and Society, 23(4): 377-410

Ramesh, A., Banwet, D.K., Shankar, R. (2010). "Modeling the Barriers of Supply Chain Collaboration”, Journal of Modelling in Management, 5(2): 176-193. 
Richardson, M. J., \& Pasupathi, M. (2005). Young and growing wiser: Wisdom during adolescence and young adulthood. In R. J. Sternberg, \& J. Jordan (Eds.), A handbook of wisdom. Psycho-logical perspectives. New York: Cambridge University, $139-159$

Rooney, D. (2013). Being a wise organizational researcher: Ontology, epistemology and axiology. In W. M. K"upers, \& D. J. Pauleen (Eds.), A handbook of practical wisdom: Leadership, organization and integral business practice. Aldershot: Gower, 79-98

Sadeghi-Fasaei, S., Naser-Rad, M. (2012). Fundamental Elements of Qualitative Research in Social Sciences (Ontology, Epistemology, Methodology and Methods), Journal of Iranian Social Studies, 5(2), 78-98. (In Persian).

Sandelowski, M., Barros, J. (2008). Handbook for synthesizing qualitative research, Springer publishing company Inc.

Schraagen, J. M., Klein, G., \& Hoffman, R. R. (2008). The macrocognition framework of naturalistic decision making. In J. M. Schraagen, L. G. Militello, T. Ormerod, \& R. Lipshitz (Eds.), Naturalistic decision making and macrocognition. Aldershot: Ashgate Publishing Limited, 3-25.

Singh, M. D., \& Kant, R. (2011). Knowledge management barriers: An interpretive structural modeling approach. International Journal of Management Science and Engineering Management, 3(2), 10.

Small, M. W. (2004). Wisdom and nowmanagerial wisdom: Do they have a place in management development programs? Journal of Management Development, 23(8), 751-764.

Soleimani H., Bashash, L. (2013). Validation of the Revised Family Needs Survey (R-FNS) Scale for Families with Children with Special Needs, 14(4), 106-120. (In Persian).

Sternberg, R. J. (2004). What is wisdom and how can we develop it? Annals of American Academy of Political and Social Science, 591(12): 164-74.

Stirling, J., (2001). Thematic networks: an analytic tool for qualitative research, Qualitative research, 1(3), 385-405.

Sweeney, C., Bernardi, R. and Arnold, D. (2014). Could the Level of Personal Indebtedness Influence an Auditor's Professional Decision-Making Process?, Research on Professional Responsibility and Ethics in Accounting (Research on Professional Responsibility and Ethics in Accounting), 18(2): 89-108. https://doi.org/10.1108/S1574-076520140000018003

Valentine, S., Godkin, L. (2019). Moral intensity, ethical decision making, and whistleblowing intention, Journal of Business Research, 98(4): 277-288

Valiyan H, Abdoli M R, Karimi S. (2018). Interpretive Structural Modeling 
(ISM) of Factors Affecting Auditor's Professional Skepticism, Iranian Journal of Value and Behavioral Accounting, 2 (4), 215-246

Valiyan, H., Abdoli, M., Koushki Jahromi A., (2019). Conceptualizing Wise Auditor Decision-Making based on Grounded Theory Approach, Accounting and Auditing Review, 26(2), 301-326 https://doi.org/10.22059/acctgrev.2019.265838.1007989

Windhorst, H. D. (2011). Loving wisdom with Dewey and Simone Weil. Analytic Teaching and Philosophical Praxis, 31(1), 41-55.

Yang, L., Brink, A, G., Wier, B. (2018). The impact of emotional intelligence on auditor judgment, International Journal of Auditing, 22(1): 83-97. https://doi.org/10.1111/ijau.12106

Zsambok, C. E. (1997). Naturalistic decision making: Where are we now? In C. E. Zsambok, \& G. Klein (Eds.), Naturalistic decision making. Mahwah, NJ: Erlbaum, 3-16.

Bibliographic information of this paper for citing:

Malekipour, Hadi; Abdoli, Mohammadreza \& Valiyan, Hasan (2021). Auditors' Wise Tactfulness in Professional Judgments by Total Interpretive Structural Modeling (TISM). Iranian Journal of Finance, 5(2), 95-127.

Copyright (C) 2021, Hadi Malekipour, Mohammadreza Abdoli, Hasan Valiyan 